\title{
Building on an oasis in Garamantian times: geoarchaeological investigation on mud architectural elements from the excavation of Fewet (Central Sahara, SW Libya)
}

Andrea Zerboni ${ }^{*}$, Andrea Bernasconi², Maria Carmela Gatto ${ }^{3}$, Caterina Ottomano1, Mauro Cremaschi ${ }^{1}$, Lucia Mori $^{4}$

1) Dipartimento di Scienze della Terra “A. Desio", Università degli Studi di Milano, via L. Mangiagalli 34, I-20133 Milano, Italy.

2) ESRF - The European Synchrotron - Grenoble, France.

3) School of Archaeology and Ancient History, University of Leicester, University Road, Leicester LE1 7RH, UK.

4) Dipartimento di Scienze dell'Antichità, Università di Roma 'La Sapienza', via dei Volsci 122, I00185 Roma, Italy.

* Corresponding author. Tel.: +39.02.50315292; Fax: +39.02.50315494; E-mail: andrea.zerboni@unimi.it

\begin{abstract}
The paper describes the micromorphological and mineralogical properties of earthen architectural elements from the excavation of the Garamantian compound of Fewet (Central Sahara, SW Libya), settled between the $2^{\text {nd }}$ century $B C$ and the $1^{\text {st }}$ century $A D$, and compares this evidence with a set of samples from historical to modern context of Saharan and Sub-Saharan Africa. At Fewet, the production of mud bricks, plasters, and mortars employed in the building of the compound required raw materials available near the settlement. The earthen elements lack almost completely clay and organic temper, and their main components are quartz grains (sandy to silty) and a calcareous and slightly organic mud, available beside former springs. Only plaster and mortars show the addition (in limited quantity) of finely subdivided vegetal remains to the mixture. The
\end{abstract}


technology for earthen elements used in Garamantian times resembles those today applied at many localities in Sub-Saharan Africa. Finally, our analyses showed that in the last millennia archaeological sediments underwent limited postdepositional weathering, mostly related to solute redistribution after occasional rainfalls. Today, the same process affects traditional mud brick buildings.

\section{Key-words}

Earthen architectural structures; Late Holocene; Saharan oasis; Garamantian period; Technological continuity. 


\section{Introduction}

Fewet is one of the three small oases clustered along the upper reaches of the Wadi Tanezzuft valley, in the Libyan Central Sahara (Bourbon del Monte Santa Maria, 1912). The oases of Fewet, Ghat, and Barkat (Fig. 1) represent the vestiges of a single, larger, Middle to Late Holocene palaeooasis running for tens of kilometres along the western flank of the Tadrart Acacus massif (Cremaschi and Zerboni, 2009, 2013).

The ancient oasis was settled by the beginning of the first millennium BC (e.g. Liverani, 2004), by a partly sedentary population (the Atarantes, according to Herodotus, contemporary to the Garamantes located in the region of the Wadi el-Ajal), which established a control of the territory of SW Libya, and exploited the natural resources sustained by local aquifers and residual rainfall. Today, modern buildings, often surrounding an ancient medina consisting of traditional houses made of mud bricks, occupy the three oases. The archaeological excavation carried out in the village of Fewet (Castelli et al., 2005; Mori, 2013) highlighted the existence, beneath the extant village, of an ancient settlement. It was composed of several compounds; the best preserved of them developed between the $2^{\text {nd }}$ century BC and the $1^{\text {st }}$ century AD (Mori, 2013). The compounds were built with mud-bearing architectural features, which are, in part, still preserved.

In this paper, we present a micromorphological and mineralogical description of earthen elements (mud bricks, plasters, and mortars) sampled during the excavation of Fewet in order to reconstruct the building technologies adopted in Garamantian times in SW Libya. Our approach includes the identification of the main sources of raw material adopted to produce earthen elements, and the interpretation the main technological and functional aspects of the sampled structures (chaînes opératoires). Moreover, we compared our results with building technologies described in modern African contexts in order to investigate if there is any technological analogy in the production of mud bricks and the preparation of plasters between the 2000 years old Garamantian village of Fewet and modern villages of the Central Sahara and Sahel. This 
comparison also aimed to distinguish between the natural depositional and post-depositional processes responsible for the preservation of the ancient earthen walls.

\section{The study area: present and past settings}

The ancient village of Fewet (Fig. 1), dating to the Garamantian period, is located in southern Libya, SW Fezzan region, in the upper reach of the Wadi Tanezzuft Valley (Latitude $24^{\circ} 56^{\prime} 57^{\prime} \mathrm{N}$, Longitude $10^{\circ} 04^{\prime} 46^{\prime \prime} \mathrm{E}$; elevation c. $600 \mathrm{~m}$ asl). The geological bedrock of the Wadi Tanezzuft consists of a homocline composed, from the West to the East, of the following Palaeozoic rock formations (El-Ghali, 2005): the Tassili sandstone (Silurian), the Tanezzuft shales (Upper Silurian), and the Acacus and Tadrart sandstone (Upper Silurian to Devonian). Strata are gently tilted toward the E-NE, in the form of a cuesta (Zerboni et al., 2015), and the valley of the Wadi Tanezzuft runs in a consequent mode along the cuesta. The wadi bottom is cut into the almost impermeable shales and thin-bedded sandstone of the Tanezzuft Formation. In the western side of the valley, along the geological contact between the Tassili and Tanezzuft Formations, suitable conditions exist for the aquifers to rise to the topographic surface; aquifers are trapped inside the highly permeable Tassili sandstone Fm. (Cremaschi and Zerboni, 2009). Groundwater sustains the palm groves and feeds the springs that are still active inside the oases of the region and up to few years ago also a small, seasonal marsh at Fewet, suggesting a very shallow depth of the water table (Cremaschi and Zerboni, 2013). The valley of Wadi Tanezzuft is filled by poorly weathered alluvial silty-clayey sediments dating to the Holocene; in the region, soils are generally thin and affected by several millennia of wind erosion (Zerboni et al., 2011; Zerboni et al., 2015).

The present climate of the Libyan Central Sahara is hyperarid. Data from the meteorological station located in Ghat indicate a mean annual temperature between $25^{\circ}$ and $30^{\circ} \mathrm{C}$ and a mean annual rainfall between 0 and $20 \mathrm{~mm}$ (Walther and Lieth, 1960). Precipitations are mostly distributed in spring and summer, and regional average annual relative humidity is $17 \%$; a 
strong wind activity is registered all the year, especially in spring, while occasional rainstorms are recorded also in the winter season.

During the Early and Middle Holocene, the region experienced a larger water availability, thanks to the huge rainfall supplied by the northward migration of the ITCZ (Intertropical Convergence Zone) and expansion northward of the SW African monsoon domain (e.g., Gasse, 2000; Gatto and Zerboni, 2015; Cremaschi et al., 2014). The water supply was considerable: it saturated the immense hydrological reservoirs of the sandstone bedrock and caused a general rise of the water table in all the physiographic units of the area (Cremaschi and Zerboni, 2009). Locally, the interruption of the humid phase is dated at c. 3500 years $B C$, when the withdrawal of the monsoon led to the progressive exhaustion of water reservoirs.

After the interruption of the monsoon rain supply to the Central Sahara, the most fragile ecosystems from the hydrological point of view (mountains, pediments, and interdune lakes) dried quickly (Cremaschi and Zerboni, 2011). Conversely, thanks to the so-called oasis effect, water availability persisted along the Wadi Tanezzuft, which survived aridification (Cremaschi and Zerboni, 2009, 2013), allowing the formation of an oasis landscape and favouring the establishing of permanent settlement and agricultural exploitation in Garamantian times. The first traces of the existence of an oasis settlement along the valley of the Wadi Tanezzuft is dated to the $2^{\text {nd }}$ millennium BC. The boundaries of the palaeo-oasis were stable in the $2^{\text {nd }}$ and $1^{\text {st }}$ millennia $B C$, but during the $1^{\text {st }}$ millennium $\mathrm{AD}$ the palaeo-oasis started contracting significantly and progressively, reaching the extant configuration of three distinct oases hosting the settlements of Ghat, Barkat, and Fewet (Cremaschi and Zerboni, 2013).

\section{The Garamantes of the central Sahara and the settlement of Fewet}

During the $1^{\text {st }}$ millennium BC the Garamantian culture spread in the Libyan region of Fezzan to form a proper kingdom, which reached its peak during the first centuries AD. At that time, the Fezzan oases became important centres, not only for permanent settlements, and irrigated 
agriculture, but also as crossroads in a network of the trans-Saharan caravan routes (Liverani, 2004; Mattingly, 2013). The Garamantian trade network spread along two major commercial routes: the transverse route from Lower Egypt to Middle Niger (NE-SW), possibly opened already from the $6^{\text {th }}$ century BC (as described by Herodotus in Historiae) (Liverani, 2004), and the northsouth routes between Tripolitania and Fezzan and between Tunisia and the Hoggar, which seem to have been opened slightly later (Mori and Gatto, 2012).

Fewet was a small village located along the Wadi Tanezzuft (Fig. 1), in the southwesternmost part of the region under the sphere of influence of the Garamantian Kingdom (Castelli et al., 2005; Liverani, 2005; Mori, 2013). It was part of a larger system including the ancient settlements of Ghat and Barkat, and was located along a NE-SW route leading from Ghat to the Tassili massif. Inside the modern village of Tan Afella (Fig. 2), at the site of ancient Fewet, a rounded compound defended by a perimeter wall made of mud bricks was excavated between 2001 and 2004 by the Italian-Libyan Mission in Acacus and Messak (University Sapienza, Rome). The settlement consisted of a series of small dwelling units (Fig. 2), mostly rectangular in shape, with walls in mud bricks that were arranged around a central courtyard with a communal well (Castelli et al., 2005; Mori, 2013; Zerboni et al., 2013). The lifespan of the compound was radiocarbon dated from the $2^{\text {nd }}$ century $B C$ to the middle of the $1^{\text {st }}$ century AD (details in: Mori, 2013). Also, surveyed and partially excavated in the Fewet oasis is a large necropolis, composed of 1329 stone tumuli, mostly dating from the $6^{\text {th }}$ century BC to the $4^{\text {th }}$ century AD, and a surface site located in the nearby village of Tan Ataram, which has been interpreted as a caravan staging post (Mori, 2013).

\section{Material and methods}

Besides the stratigraphic archaeological excavation of the compound (Mori, 2013), a geoarchaeological investigation, mostly based on thin section analysis and mineralogical determinations, was carried out (Zerboni et al., 2013, 2017). The micromorphological study of 
floors and mud bricks, mortars, and plasters contributes to understand the stratigraphy and the materials, technological and functional aspects of selected features, and taphonomic processes involved in the formation of the archaeological record (McIntosh, 1974; Goldberg, 1979; Courty et al., 1989; Miller Rosen, 1986; Shahack-Gross et al., 2004 Goodman-Elgar, 2008; Macphail and Goldberg, 2010; Shillito et al., 2013; Matthews et al., 2013; Banerjea et al., 2015; Friesem et al., 2017; Cammas, in press). For this purpose, a set of in situ and undisturbed blocks was collected from preserved earthen structures; the position of each sampling point is shown in the general plan of the excavation of Figure 3. Samples can be distinguished into three groups: (i) mud bricks, belonging to in situ and collapsed walls dating to the Garamantian period of the compound (four samples: MB1; MB2; MB3; MB4), (ii) wall plaster (three samples: PL1; PL2; PL3), and (iii) mortar (two samples: MT1; MT2). Moreover, six comparison samples were taken from contemporary settlements: a few hundred years old mud brick collected in the old town of Ghat (less than $10 \mathrm{~km}$ from Fewet); a modern mud brick from Mopti (a city in Mali); two modern mud bricks and a sample of plaster from Al Khiday (a village in the central Sudan; Usai and Salvatori, 2002); one mud brick from a historic building in Omdurman (Sudan); a mud brick from the Meroitic excavation at Dangeil that was provided by the Berber-Abidiya Archaeological Project (Sudan).

Thin sections $(5 \times 9 \mathrm{~cm})$ were prepared at Servizi per la Geologia Lab. (Piombino, Italy) after consolidation with polyester resin according to the method described in Murphy (1986). Micromorphological studies of sediment thin sections employed an optical petrographic microscope (Olympus BX41, with a digital camera, Olympus E420) at various magnifications (16x, 20x, 40x, 100x, 200x, 400x, 1000x); thin sections were observed under plane-polarized light (PPL), cross-polarized light (XPL), and oblique incident light (OIL). In thin-section description, the terminology of Stoops (2003) was used. In the interpretation, we followed many of the concepts discussed in Courty et al. (1989), Stoops et al. (2010), and Nicosia and Stoops (2017). Results of thin 
sections study are briefly presented in the Result section and reported in detail in Tab. 2; in the same table some field properties of investigated features are reported.

XRD (X-ray powder diffraction) analysis was performed on collected samples of mud bricks, plasters, and mortars in order to clarify the mineralogical composition of specific features. A further sample was collected from the swamp deposit very rich in organic matter found near the compound (sample Marsh). X-ray powder diffraction measurements were carried out using a X'Pert Panalytical Diffractometer working in Bragg-Brentano geometry and equipped with an $X^{\prime}$ Celeretor Detector. Each sample was manually grinded in an agate mortar and then analyzed in the $3-80^{\circ} 2 \theta$ range $(\mathrm{Cu}$-wavelength, $40 \mathrm{kV}, 40 \mathrm{~mA})$ with a step size of $0.02^{\circ}$ and a counting time of 20s. Qualitative mineralogical phase analysis was performed based on peak position (Klug and Alexander, 1974), and indications about abundance of each mineral phase were obtained on the basis of peaks intensities. We decided to create four different classes of abundance: ++++ if peaks are dominant, +++ if peaks can be observed over the entire range, ++ if the main peak is well visible but it is hard to distinguish the other peaks from the background, and + if the main peak can be just distinguished from the background.

\section{Results}

\subsection{Description of earthen architecture at Fewet}

The excavated compound was planned and built as a single structure, for the dwelling of an enlarged family or small clan with an egalitarian socio-economic base (Liverani, 2005; Mori, 2013). The settlement had a defensive nature and was planned as an enlarged household, with a single gate and a communal well, which ensured water availability (Fig. 4). The whole settlement was built with mud bricks, using sandstone blocks for the wall's foundations. A central courtyard allowed the inner circulation and provided a protected space for working activities, like the threshing and grinding of cereals, and basketry and leather items production, which needed larger spaces not provided by the relatively narrow roofed areas (Mori, 2013). 
The covered rooms were built along the compound wall's perimeter, and were generally arranged in units composed of two rooms: a larger square room flanked by a smaller rectangular one (Fig. 4). Remains of the original roofs were found only in three of the excavated rooms, which burnt down and collapsed on the floors. Roofs were built in a similar way to the traditional local architecture, with a frame of long beams of palm or tamarisk wood, covered by tree branches, small wooden sticks, and mats stabilized with mud (Mercuri et al., 2013).

Building techniques and materials are rather homogeneous: roughly dressed sandstone slabs (or at least sandstone outcrops) were used almost exclusively for the mud brick wall foundations and for the footing of the perimetral village wall (Fig. 4). Mud bricks were highly standardized both in composition and size $(50 \times 35 \times 8 \mathrm{~cm})$, thus suggesting the use of moulds for their production. The compound's wall was up to $4.5 \mathrm{~m}$ high, while inner rooms, according to the excavated collapses, were at least $2.6 \mathrm{~m}$ high (Mori, 2013).

\subsection{Thin sections' micromorphology of mud architectural elements}

\subsubsection{Mud bricks}

The five samples of mud bricks show a degree of homogeneity in visual, microscopic, and mineralogical composition (see details in Tabs 1 and 2). In the field, mud bricks generally have a prismatic structure, very pale brown to light yellowish brown in color (from 10YR 7/4 to 10YR 6/4), with a hard consistency, and made of sand, fine silt, and clay with interspersed coarser and well rounded fragments of light yellow (2.5Y 7/4), calcium carbonate nodules.

Under the microscope (Tab. 1), mud bricks display a massive structure (Fig. 5A), in few cases they show a polyedric structure. Voids are scarce to common and consist of vesicles (the most represented), channels, and vughs; sporadically, we notice the occurrence of pseudomorphic voids (Fig. 5B,C), retaining the shape of chaff eventually added as temper (Courty et al., 1989; Gé et al., 1993; Friesem et al., 2017). In most of the thin sections, two intermixed types of micritic micromass can be distinguished: one (which generally dominates) is opaque, light yellowish 
brown in color (under PPL and XPL); whereas the other one is dusty, light gray to light brown, and includes very small elongated to rounded dark minute organic particles (Fig. 5A). The mineral fraction consists of poorly rounded, silty to medium sandy quartz grains. The latter display an external thin layer of reddish iron oxides. Thin section analysis evidenced a generalized absence of organic components in mud bricks. Occasionally, we found small and angular charcoal fragments, cluster of phytoliths, unburned vegetal remains, and oxidized organic fragments. Moreover, the occurrence of vegetal fibres, phytoliths, and clusters of faecal spherulites (Fig. 5D-F) highlights the uncommon presence of fragmented coprolites, presumably ovicaprine pellets (Brochier, 1996; Canti, 1997, 1999). In the slides, sub-rounded to angular coarse carbonatic nodules were found; they are clearly distinguishable from the micromass due to a brown to gray-brownish (under PPL and XPL respectively), opaque color, and the lack of coarse mineral grains. Calcium carbonate nodules should be interpreted as pedorelicts (Fig. 6A, B). Few very small rounded soil aggregates, displaying evidence of modest heating, can be attributed to the same micropedological category. The larger $\mathrm{CaCO}_{3}$ nodules are few millimetres in diameter; their microstructure comprises of layers of micro- and macro-calcite and some infillings, consisting of microcrystalline and palisades $\mathrm{CaCO}_{3}$ crystals (Fig. 6). The general aspect of carbonate inclusions displays many analogies with stromatolite-like sedimentary features. Diatoms, sponge spicules, freshwater shell fragments, and microfossils of freshwater (possibly belonging to genus Chara; Premoli Silva, pers. comm.), indicates that carbonated formed in a freshwater sedimentary environment (Fig. 6). They can be attributed to palustrine/swamp carbonates or spring tufa, which largely formed in the region in the Early and Middle Holocene (Cremaschi et al., 2010; Zerboni et al., 2015). Other, less represented, pedofeatures are: Fe-bearing oxides impregnating the micromass, calcite neoformation along planar voids, and, in the case of sample MB4, cracks discontinuously filled by loose, randomly oriented lenticular gypsum crystals.

\subsubsection{Plasters}


Plasters were sampled in correspondence of earthen walls preserved in situ and not from the

collapsed ones, as in the latter case plaster generally underwent strong diagenesis or erosion. Plaster applied to walls has a silty to sandy, grey to light yellowish brown (from 10YR 5/1 to 10YR 6/4) groundmass, which includes small light yellow (2.5Y 7/4) angular aggregates.

In thin section, plaster appears less massive than a mud brick. Voids (vughs, channels, and vesicles) are common, but in some portions of the slides they are rare, probably due to higher compaction of the groundmass (Fig. 7A). Locally, channels and vesicles are oriented along the same direction and they may correspond to pseudomorphic voids (Fig. 7A). The groundmass is rich in clay with interspersed common to abundant, subrounded to angular, silty to fine/medium sandy quartz grains; it is yellow and slightly birefringent (under XPL). Within plasters, constituents of organic origin are more common than within mud bricks. They consist of few small, angular fragments of charcoal, unburned and well preserved vegetal remains, and very few phytoliths concentrations (Fig. 7B). The groundmass includes sub-rounded to angular, mammilate carbonatic nodules (like those described for mud bricks). The most common pedofeatures are crystalline and are represented by randomly oriented, lenticular gypsum crystals (Fig. 7C). The latters were found in the groundmass as growths of lenticular euhedral gypsum crystals (up to some hundreds of microns long), and as dense infilling in vughs, chambers and channels and dense-to-loose, almost continuous infilling along planes and cracks (Fig. 7D).

\subsubsection{Mortars}

During the excavation, mortars were less evident than other mud elements; this fact is probably due to their limited thickness. For that reason, only two, well-preserved samples of mortar were collected for thin sections' analysis. Mortars displays a silty to sandy groundmass with a pale brown-light yellowish brown to dark gray color (10YR 6/3-10YR 6/4 to 10YR 4/1), with interspersed light yellow (2.5Y 7/4), small angular aggregates. 
In thin sections, mortars are highly compacted, with few voids. We distinguished two main

types of fabric: one is rich in brilliant yellow and birefringent clay (Fig. 8A), whereas the other is opaque and light grey to brownish. The latter shows a diffuse impregnation of calcite and amorphous organic particles (Fig. 8B). Sub-rounded to angular, Fe-stained silty to medium/coarse sandy quartz grains are interspersed in the groundmass; sometimes they display a preferential horizontal orientation (Fig. 8C, D). Very few angular, moderately preserved vegetal remains and clusters of phytoliths are present. Few large lenticular crystals of gypsum (single units or in cluster) are present in the groundmass.

\subsubsection{Comparison samples}

Mud brick comparison samples were selected among modern and ancient African contexts to compare the production technology and test its continuity through centuries. Ghat is one of the oldest Saharan cities (Bourbon del Monte Santa Maria, 1912) and the comparison mud brick comes (according to local informants) from a building in the oldest part of the city. Mopti was founded as a mud brick village in the XVIII century (Cailliè, 1830) and become a large city under the French occupation since the beginning of the last century (de Benoist, 1998). Comparison sample dates to the latter period. Mud brick samples from Sudan include: three recently produced mud bricks from the village of Al Khiday that was established few tens of years ago; a mud brick from an historic building in Omdurman (Kramer et al., 2013) that dates back (according to local informants) to the beginning of the last century; a mud brick from the Late Kushite ( $3^{\text {rd }} \mathrm{Cent}$. BC $4^{\text {th }}$ cent. AD) city at Dangeil (Anderson et al., 2015, 2017).

The thin section of a modern mud brick collected at Ghat shows many similarities with those from ancient Fewet. It shows a very massive structure with very scarce vughs and vesicular voids (Fig. 9A). It consists of a mixture of quartz grains in a clayey to calcitic micromass, and present very few vegetal inclusions. The mud brick from an historic building in Mopti is massive and hard, with very few vegetal inclusions and voids. Under the microscope, it largely consists of 
sand to silt quartz grains, with interspersed few elongated vegetal remains (possibly straw or

grass), common red, Fe-oxides-rich rounded pedorelicts, and common fragments of former clay coatings and infillings (Fig. 9B, C).

Mud bricks from the Meroitic buildings in Dangeil and those from the modern buildings in Al Khiday are massive and hard, and vegetal inclusions are almost lacking. In thin section, these samples display a sandy to silty groundmass, almost consisting of quartz grains (Fig. 10A-C); clay is also represented. In the groundmass, several pedorelicts consisting of fragments of decantation crust are present (Fig. 10A, C). Plaster from one of the buildings in Al Khiday display a typical laminated structure, with millimetric compact laminae rich in quartz grains, it is richer in organics (straw and coprolite fragments) than mud bricks (Fig. 10D, E). On the contrary, the mud brick from a historic building in Omdurman shows a great abundance of vegetal remains added to a mineral mixture, consisting mostly of sand, silt, and fragments of decantation crusts (Fig. 10E).

\subsection{Mineralogical determinations}

Results of X-ray diffractions are represented in the Tab. 2 and in the diagrams of Fig. 11; in the latter, labels represent the mineralogical phase of the corresponding peaks. As evident, the mineralogical composition of each analysed sample is almost homogeneous, with few differences in the less represented mineralogical species. XRD on mud bricks evidenced that they are dominated by quartz and calcite, while K-feldspar and plagioclase are occasionally present. X-ray diffractions on plaster bulk samples rendered a mineralogical composition dominated by quartz, while calcite, kaolinite, and gypsum, are less represented. K-feldspar is present in samples PL1 and PL3; halite is in samples PL2 and PL3; and in one case (PL2) mica was detected. XRD on mortars evidenced a large quantity of quartz and calcite, with K-feldspar and plagioclase less represented; furthermore, in sample MT1 gypsum is present, whereas kaolinite was detected in sample MT2. The mineralogical composition of the organic matter-rich marsh deposit near the compound of 
Fewet (sample LK) was considered as a possible source. It highlighted a high content of quartz, calcite, kaolinite, and gypsum, whereas halite, mica, and plagioclase are less represented.

\section{Discussion: building technology of earth-based elements}

Mud technology is widespread in arid environments because it offers two main advantages. In one hand, mud bricks are easy to produce, as raw materials are largely available and low-cost, and earthen-based houses are fast to build. Moreover, mud brick houses have good thermal insulation to withstand extreme environmental conditions. During the warm season, mud walls gradually warm up from the outside during the day, while at night they cool down again, thus helping the interior of the rooms to stay cool all day long (Zerboni et al., 2013). Notwithstanding that, if we compare the architectural elements preserved at Fewet with those described at other Garamantian archaeological sites, we notice that in our case an earthen-based building technology was largely employed, while elsewhere it was limited to marginal structures or features. At Aghram Nadharif, a citadel few kilometres eastward Fewet, in hill-top sites such as Zinchecra, in the Wadi el-Ajal, and in several castles/forts located along the main caravan routes of the Fezzan region. The inhabitants made a large use of stones, especially in the building of foundations and outer fortification walls, while earthen architectural elements were used for the inner rooms' walls or smaller architectural elements such as small storage bins (Mattingly et al., 2003; Liverani, 2005; Biagetti and di Lernia 2008). This difference could be related to defensive reasons, to a large availability of stone slabs (the citadel was built on top of a sandstone outcrop), or to the limited availability of water and other natural resources, thus making difficult the production of mud bricks.

\subsection{Raw material supply}

The composition of mud elements from the compound of Fewet suggests a homogeneous choice of primary mineral components to produce mud bricks, plasters, and mortars. Based on the 
comparison with the local geological context, we can suggest some considerations on the

procurement of the mineral components of the mixture used for earthen elements.

Quartz grains are largely available in the Central Sahara, as well as along the Wadi Tanezzuft. They originate after the dismantling of the local bedrock, which consists of almost pure quartzarenite (El-Ghali, 2005). The exploitation of quartz grains from primary wind blown sand or sediments shortly mobilized by fluvial activity is suggested by the shape and roundness of grains and by the presence of grains stained by Fe-oxides, which is typical of local soils (Zerboni et al., 2011; Zerboni et al., 2015; Knight and Zerboni, 2018). The clay evidenced in the micromass of mud elements was probably found in correspondence with local soils, which display moderate clay content, including kaolinite (Zerboni et al., 2011). Slides of plaster evidence a larger occurrence of clay and they have many similarities with the fabric of the B horizons of the Pleistocene and Early Holocene soils described in the region (Zerboni et al., 2011).

The carbonatic nodules and freshwater fossils found in earthen elements show a specific sedimentary facies, suggesting they formed in shallow waters. Freshwater carbonates (spring tufa and carbonatic limnites) are common in the region, and their depositional environments have been described in several papers (e.g., Cremaschi et al., 2010; Zerboni et al., 2015). The geomorphological survey of the area surrounding Fewet evidenced the occurrence of an active spring near the compound (few tens of meters), located near a wide outcrop of organic matter-rich deposits with a moderate to low carbonatic fraction (Tab. 2), which formed in a marsh environment during the Middle Holocene (Cremaschi and Zerboni, 2013). The facies of some calcite-bearing components observed in thin sections belongs to a different kind of lacustrine sedimentary environment, like the whitish deposit identified at the foot of the easternmost fringe of the Tassili Massif (Fig. 2). Carbonates were possibly provided from this place and the organic mud from the spring deposit, thus explaining the occurrence of the differentiated groundmass of mud bricks: one calcitic, the other richer in amorphous organic matter. The presence of few calcite crystals (pseudomorphs after calcium oxalates, which originate from wood ash) in some slides 
suggests that wood ash could be added to the mixture, as observed also at other sites (Miller

Rosen, 1986; Goren and Goldberg, 1991; Varanda, 2001).

The identification of sources for raw material suggests the use of proximal resources for building the compound of Fewet. Our interpretation is supported by descriptions of adobe and plaster technology form several sites in the Sahel, West Africa, Morocco, and the Nile Valley, which report the use of raw materials sources from earth pits close to the sites (Prussin, 1974; McIntosh, 1974; French, 1984; LaViolette, 1994; Mattone, 2003; Pecquet, 2004; Macphail and Goldberg, 2010; Nicolini et al., 2010).

Mud elements from the Central Sahara lack of vegetal temper; for that reason they differ from most of the archaeological contexts in the circum-Mediterranean, which are charatcterised by abundant straw and dung added to the earthen blend (Carter and Pagliero, 1966; Goldberg, 1979; Miller Rosen, 1986; Kemp, 2000; Stevanocic, 1997; Nodarou et al., 2008). A mixture for mud elements poor in vegetal temper is recorded at protohistoric and historic archaeological sites in Southern France (Cammas, 2003, 2015, in press). At Fewet, the general absence of preserved organics in the groundmass and the very occasional occurrence of pseudomorphic voids (moldic voids, Goldberg, 1979) retaining the shape of chaff after its decay, suggest that mud elements were not intentionally plant-tempered. Organic remains are almost lacking in the mud brick from ancient Ghat, and, in the region, Liverani (2005) reported that the few mud bricks found at Aghram Nadharif are almost free of vegetal remains. We noticed that also the mud bricks from Mopti, Dangeil, and Al Khiday have few vegetal fragments added to the mixture. The sporadic occurrence in samples from Fewet of constituents that may result from the intentional cleaning of a living floor such as fragments of ovicaprine coprolites, charcoal fragments, vegetal remains, and heated pedorelicts (Courty et al., 1989; Macphail and Goldberg, 2010; Zerboni, 2011) suggests that the production area was close to the settlement.

Possibly, within the oasis dung, grass, straw, and cereal husks were scarce and represented a precious resource in domestic economy; they were employed as fuel in domestic fireplaces 
(Zerboni et al., 2017), to feed domestic animals (Biagetti, 2014; Éguez et al., in press), or as inclusion

in pottery fabrics (Gatto, 2010). A building technology like the one described at Fewet is reported by several authors (Beck and Huard, 1969) for the Tebu people living in the Tibesti region (southeastern Fezzan), who used to produce mud bricks by mixing water, sand, and fluvial silt. At a continental scale, we found more technological correlations. At Kerma (Sudan) archaeological mud bricks exhibit a very low content of straw and charcoal as temper to prevent brick shrinkage (Nicolini et al., 2010). Moreover, in Sudan also Meroitic and modern buildings are made of siltdominated mud bricks with few or at least with no organic temper. As stated before, the building technology adopted at Fewet in Garamantian times seems to be simple, but it is effective; in fact, almost the same method was widely adopted in a large part of the Sahel, from Burkina Faso to Mali, to build up religious edifices and houses (Prussin, 1974; McIntosh, 1974, 1977; Maas and Mommersteeg, 1992; LaViolette, 1994; Fiedermutz-Laun, 2005).

Our results highlighted some other analogies between earthen architectural elements adopted in ancient Fewet and the one described for the Sahel and observed at Ghat, Al Khiday, Dangeil, and Mopti. In fact, the addiction of fine-textured and rolled nodules, pedorelicts, and surface crust fragments, which possibly represents the intentional addition as temper of former building debris (Miller Rosen, 1986; Nodarou et al., 2008; Macphail and Goldberg, 2010), is a practice reported from some contexts from the Sahel (Maas and Mommersteeg, 1992; LaViolette, 1994). Moreover, if we compare mud brick architectures from Fewet with the sample from ancient Ghat, Mopti, and Al Khiday, we notice a similar occurrence of quartz grains. Some reports on modern adobe from the Sahel (LaViolette, 1994) and the Nile Valley (French, 1984) confirm they are enriched with local sand. This is expected, as quartz sand is the most common Quaternary sediment over continental North Africa.

\subsection{Technological aspects of earthen buildings}


The identification of the basal floor of the compound described in Zerboni et al. (2017), which lies

on the sandstone bedrock, suggests that at least part of the village was built directly on the bedrock after levelling the rock surface and positioning mud bricks on it. Comparative ethnographic and historical sources show that African mud brick buildings usually stand on none or shallow foundations, excavated for few tens of centimetres (Prussin, 1974; LaViolette, 1994; Mattone, 2003; Mori, 2013). The remnant part of the compound was built on a soft substrate. A single row of sandstone slabs acted as foundations, as commonly observed at many modern and ancient African sites. At the end of the excavation at Fewet (year 2004), the compound was encircled by a mud brick wall, planned to protect the archaeological site. It was built according to traditional techniques (Fig. 12): a single row of sandstone blocks, taken from an outcrop located less than $100 \mathrm{~m}$ far from the site, was used as foundation. Mud bricks were made in wooden moulds just few tens of meters far from the site (Fig. 12), were the sandy-silty sediments of a marsh deposit were available.

The most significant difference in the technology of earthen elements between Fewet and those described in the Levant (Miller Rosen, 1986) is the absence of straw and/or dung This kind of temper generally prevents bricks from cracking and increases their resistance to anthropic and environmental stresses. But if we look at the technologies to produce earthen features reported from historical and ethnographic (i.e., modern) contexts, those from contemporary Fewet and Ghat, from many localities of northern and central Africa (Prussin, 1974; McIntosh, 1974, 1977; Maas and Mommerstee, 1992; LaViolette, 1994; Fiedermutz-Laun, 2005), and the examples form Mopti, Dangeil, and Al Khiday we can find many analogies in the preparation of traditional adobe. Prussin (1974) suggests that deposits rich in sand are rarely employed in manufacturing traditional African adobe; in fact, the blends would not reach the cohesiveness required to build. As confirmed by our observations on the mud brick from Mopti, soil/sediments richer in clay are preferred, as much as in the sample from Al Khiday, where pedorelicts present high clay content. Moreover, sometimes adhesive and hardening agents (dung and vegetal remains) making adobe 
lighter and more resistant to stress can be added. A limited availability of clay-rich raw material

near Fewet obliged the local population to find material suitable to produce mud elements. In fact, in the area soils are generally discontinuous (due to strong erosion) and Bt horizons are very thin (Zerboni et al., 2011; Cremaschi et al., in press). At Fewet, to solve the problem of cohesion of mud bricks, a high quantity of calcium carbonate-rich sediments was added to the earthen mixture. In this way, the final product was hardened by the recrystallization of calcite in the groundmass after mixing to water and baking in the sun, which creates a semi-cemented final product (Miller Rosen, 1986; Macphail and Goldberg, 2010). This methods is also reported from several contexts in the Near East and Mediterranean region (Miller Rosen, 1986; Goren and Goldberg, 1991; Pinińska and Hemdan, 2008).

At Fewet, we notice some differences in the mixtures used to produce mud bricks and the one of the plaster for refining walls, being the latter richer in carbonate, sand, and organics. An explanation is offered by comparing our case study with the production of banco (a specific blend of clay, sand, cereal husks largely adopted as plaster; Pecquet, 2004) in modern Sahelian contexts. The preparation of banco without cracks requires lower clay content and a higher percentage of sand than mud bricks (Prussin, 1974; Maas and Mommersteeg, 1992; LaViolette, 1994). Moreover, the occurrence of minute vegetal fragments in plasters from Fewet is comparable to the blend used in Mali and Burkina Faso for banco, which is obtained mixing the mineral fraction with rice, millet, or barley husks to improve wall rendering (LaViolette, 1994; Varanda, 2001). We observed the addiction of few straws and cereal husks also in the Sudanese plaster.

\subsection{Post-depositional processes and preservation of earthen archaeological structures}

At the archaeological site of Fewet, evidence of post-depositional processes is related to gypsum redistribution, which occurred in most of the layers, and especially in those directly related to firing activities (see Zerboni et al., 2017). Due to the high availability of gypsum within archaeological layers, the process of its redistribution was strong enough to slightly affect also 
earthen architectural elements. In fact, we noticed the occurrence of intergrowths of single or sparse gypsum crystals and nodules infilling the voids in slides from plasters and mud bricks.

The main process promoting the redistribution of gypsum within earthen elements is an enhanced evapotranspiration (Courty et al., 1989; Poch et al., 2010), triggered by increased aridity during the last centuries (Cremaschi and Zerboni, 2009). Therefore, gypsic pedofeatures are related to post-depositional processes of water movements within the upper part of the stratigraphic record. Gypsum is more common in plaster, which is the outer and most porous earthen material. On the contrary, mud bricks have a massive and less porous microstructure, possibly occluding the circulation of water rich in solutes.

The occurrence of gypsic pedofeatures in the voids of the most porous elements of earthen structures may be responsible for the decay of the walls of the compound of Fewet (Fig. 13). The main process of weathering of mud walls has been observed in recent and ancient earthen buildings in the Sahel and the Levant (Carter and Pagliero, 1966; McIntosh, 1974; Miller Rosen, 1986; Goodman-Elgar, 2008; Pininska and Hemdan, 2008; Friesem et al., 2011). It consists of capillary translocation of moisture and salts crystallization in interstitial pores, triggering the superficial flaking of the wall. After that, under the influence of gravity and due to the undercutting of basal lines of bricks (Fig. 14), the wall looses structural consistency and collapses (McIntosh, 1974).

From a general point of view, the climate and environmental settings of the Sahara largely prevent the preservation of mud elements in an archaeological site (McIntosh, 1974; Friesem et al., 2011), mostly due to i) strong wind erosion, which is the main natural factor promoting the dismantling of the archaeological record, and ii) enhanced evapotranspiration, which contributes to the physical and chemical alteration of sediments (e.g., McIntosh, 1974; Miller Rosen, 1986; Goodman-Elgar, 2008; Pininska and Hemdan, 2008; Friesem et al., 2011). Moreover, the presence of a growing village represented a great menace for the survival of the archaeological record. The Garamantian compound of Fewet was endangered by both hazards: extremely severe arid climate 
negatively impacts on the stratigraphy, while later human disturbance seriously altered part of the archaeological structures. Notwithstanding that, in our case study a rapid burying of archaeological remains (Fig. 13) allowed a good state of preservation of the architectural structures (Carter and Pagliero, 1966).

\section{Conclusions: the earthen architecture of southern Fezzan in Garamantian times and its archaeological relevance}

The geoarchaeological study carried out at Fewet on earthen architectural elements allows to elucidate the building technologies adopted by the local population of the region in Garamantian times.

The rural compound of Fewet was partly built on the local geological bedrock, after a rough levelling of the surface. Lacking rich plant or dung reserves, the people of Fewet started producing mud bricks and muddy blends for plaster and mortar with local mineral resources. A mixture basically composed of sand, clayey sediments, and carbonates improved the building resistance to local environmental stress. In the Wadi Tanezzuft region, the Fewet compound was the earliest residential structure built in mud bricks dating to the $3^{\text {rd }}-2^{\text {nd }}$ centuries $B C$. But the craft and standardization of the mud bricks work implies an introduction and experimentation in the area, prior to the $2^{\text {nd }}$ century BC, for which we lack any archaeological evidence, yet (Mori, 2013). Mud bricks technology was probably introduced in the Wadi Tanezzuft from the Wadi el-Ajal region, where the earliest attested mud bricks were dated to the $4^{\text {th }}$ century BC (Mattingly, 2013). At the hilltop site of Zinkekra the earliest experiments with building materials new to the Fezzan region (mud brick and dressed stones) and new building forms (multi-roomed complex rectangular houses) took place in the latter centuries BC (the so-called Proto-Urban Garamantian phase, see Mattingly et al., 2003). It has been suggested that the appearance of these new techniques at ancient Jerma was related to the introduction of the foggara irrigations system and introduced from the oases of the Egyptian Western Desert (Mattingly, 2013). The scanty available 
information apparently indicates that the introduction of mud bricks architecture in Sub-Saharan

West Africa occurred at the beginning of the $1^{\text {st }}$ century AD (the site of Dia-Shoma, in the inner Niger Delta; MacDonald, 2011). The Fewet evidence might represent a geographic and chronological nexus in a theoretical north-east/south-west diffusion of earthen architecture. In fact, the mud architectures at Fewet have few analogies with those described in the Near East, but they are strictly related to those adopted in the Saharan and Sahelian belts of Africa.

Our conclusions have to be supported by further systematic geoarchaeological and micromorphological study of African contemporary architectural earth remains. In any case, we suggest that in each case study here considered raw materials used to prepare mud bricks were proximal to the production site. Moreover, we found evidence of technological continuity from the early historical times till today, as confirmed by the traditional buildings in modern Fewet and Ghat (Fig. 16). This continuity also represents an interconnection between Fewet and both the northern region of the Wadi el-Ajal, and the southernmost fringes of the Sahara (Mori, 2013). The hypothesis of a technological analogy mostly relies on micromorphological data and comparison with contemporary ethnographic evidence from the Sahelian region (as in the case of Mopti and $\mathrm{Al}$ Khiday) and with the historic case of Dangeil; the latter site is almost contemporaneous with the compound of Fewet. Notwithstanding this, building technology over the region may have changed across time, according to the local availability of certain resources such as vegetal matter, animal dung, or water. In Garamantian times, the production of mud features was identical to that employed for many centuries afterwards in the same region and in the whole Sub-Saharan Africa. Even though micromorphological and mineralogical studies are not available for adobe and plaster from contemporary and historical African contexts (a part from the samples here discussed), the mixture of ingredients used in banco technology widely employed in Mali and Burkina Faso resembles the one described in our study.

The introduction of mud bricks in the Fezzan is apparently related to the use of a rectangular module for dwelling units, which is well attested both in the Wadi el-Ajal and at Fewet 
(Mattingly et al., 2003; Mattingly, 2013; Mori 2013). Nevertheless, in our study region, the

rectangular plan of the houses is inserted in a circular or ovoidal plan of the compound, whereas in the Wadi el-Ajal an orthogonal arrangement is preferred (Mattingly and Sterry, 2013). This cultural trait points, once more, to older African models of dwelling (the Tichitt tradition for example), to which our region may have been related (Mori, 2013).

\section{Acknowledgments}

The research has been carried out under the aegis of the Italian-Libyan Archaeological Mission in the Acacus and Messak, Sapienza University of Rome and Department of Archaeology, Tripoli, at present directed by S. di Lernia. The archaeological project on the Garamantian sites along Wadi Tanezzuft was established by M. Liverani. Main funds for field excavation at Fewet come from Sapienza Università di Roma (Grandi Scavi di Ateneo) and Italian Ministry of Foreign Affairs (DGSP) entrusted to M. Liverani and S. di Lernia. Financial support for thin sections and XRD analyses was provided by Università degli Studi di Milano - Linea B (to A. Zerboni) and the Shelby White - Leon Levy Program for Archaeological Publications (to L. Mori). Mud bricks from Sudan were collected during an archaeological mission to Central Sudan, directed by D. Usai (CSSeS), who is kindly thanked; funding for travelling in Sudan are from Fondi Speciali per le Ricerche Archeologiche (Univeristy of Milano) entrusted to AZ. We acknowledge J.R. Anderson, R.K. elRasheed, and K.S. Bashir (Co-Directors Berber-Abidiya Archaeological Project) for providing mud bricks from Dangeil. K. Herforth is thanked for providing a mud brick from Mopti. AZ would like to express his gratitude to C. Lancelotti and S. Biagetti for being invited to the Empty spaces or creative interfaces? A multi-scalar perspective on current dryland archaeology meeting held in Barcelona (2017). 


\section{References}

Anderson, J., Bashir, S.M., el Rasheed, R.K., 2015. The Qatar-Sudan Archaeological Project at Dangeil Satyrs, Rulers, Archers and Pyramids: A Miscellany from Dangeil 2014-15. Sudan \& Nubia 19, 88-94.

Anderson, J., el Rasheed, R.K., Bashir, M.S., 2017. QSAP Dangeil 2016: 'Aspelta, Beloved of Re'Harakhty and Tombs in the Temple. Sudan \& Nubia 21, 159-168.

Banerjea, R.Y., Bell, M.G., Matthews, W., Brown, A.D., 2015. Applications of micromorphology to understanding activity areas and site formation processes in experimental hut floors. Archaeological and Anthropological Sciences 7, 89-112.

Beck, P., Huard, P., 1969. Tibesti carrefour de la prehistoire Saharienne. Editions Arthaud, Paris.

Biagetti, S., 2014. Ethnoarchaeology of the Kel Tadrart Tuareg. Pastoralism and Resilience in Central Sahara. Springer Briefs in Archaeology. Springer International Publishing.

Biagetti, S., di Lernia, S., 2008. Combining intensive field survey and digital technologies: new data on the Garamantian castles of Wadi Awiss, Acacus Mts., Libyan Sahara. Journal of African Archaeology 6, 57-85.

Bourbon del Monte Santa Maria, G., 1912. L'oasi di Ghat e sue adiacenze. Città di Castello, Comando del Corpo di Stato Maggiore (Ufficio Coloniale). Tipografia dell’Unione Arti Grafiche, Firenze.

Brochier, J.E., 1996. Feuilles ou fumiers? Observations sur role des poussieres spherolitiques dans l'interpretation des depots archeologiques holocenes. Anthropozoologica 24, 19-30.

Caillié, R., 1830. Travels through Central Africa to Timbuctoo; and across the Great Desert, to Morocco, performed in the years 1824-1828. Colburn \& Bentley, London.

Cammas, C., 2003. L'architecture en terre crue a l'age du Fer et a l'epoque romaine: apports de la discrimination micromorphologique des modes de mise en oeuvre. In: Chazelles, C.-A. de, Klein, A., Acetta, A., (Eds.), Echanges transdisciplinaires sur les constructions en terre crue 1, 
Terre modelee, decoup_ee ou coffree, Materiaux et modes de mise en oeuvre, Proceedings of

a Conference Held 17-18 November 2000. L'Esperou Ed., Montpellier, France.

Cammas, C., 2015. La construction en terre crue de l'age du Fer a nos jours, l'apport de la micromorphologie a la comprehension des techniques. Archaeologies 42, 58-67.

Cammas, C., in press. Micromorphology of earth building materials: Toward the reconstruction of former technological processes (Protohistoric and Historic Periods). Quaternary International. https://doi.org/10.1016/j.quaint.2018.01.031

Canti, M.G., 1997. An investigation of microscopic calcareous spherulites from herbivore dungs. Journal of Archaeological Science 24, 219-231.

Canti, M.G., 1999. The production and preservation of faecal spherulites: animals, environment and taphonomy. Journal of Archaeological Science 26, 251-258.

Carter, T.H., Pagliero, R., 1966. Notes on mud-brick preservation. Sumer 22, 65-76.

Castelli, R., Cremaschi, M., Gatto, M.C., Liverani, M., Mori, L., 2005. A preliminary report of excavations in Fewet, Libyan Sahara. Journal of African Archaeology 3, 69-102.

Courty, M.-A., Goldberg, P., Macphail, R., 1989. Soil and micromorphology in archaeology. Cambridge: Cambridge University Press.

Cremaschi, M., Trombino, L., Zerboni, A., (in press). 29. Palaeosoils and relict soils, a systematic review. In: Stoops, G., Marcelino, V., Mees, F. (Eds.), Interpretation of micromorphological features of soils and regoliths - Revised Edition. Elsevier. doi.org/10.1016/B978-0-444-63522$8.00029-2$

Cremaschi, M., Zerboni, A., 2009. Early to Middle Holocene landscape exploitation in a drying environment: Two case studies compared from the Central Sahara (SW Fezzan, Libya). C.R. Geoscience 341, 689-702.

Cremaschi, M., Zerboni ,A., 2011. 5. Human communities in a drying landscape. Holocene climate change and cultural response in the central Sahara. In: Martini, I.P., Chesworth, W., (Eds.), Landscape and Societies, Selected cases. Springer Science. DOI: 10.1007/978-90-481-9413-1_5. 
Cremaschi, M., Zerboni, A., 2013. 2. Fewet: an oasis at the margin of Wadi Tanezzuft (Central Sahara). In L. Mori (Eds.), Life and death of a rural village in Garamantian Times. Archaeological investigations in the Fewet oasis (Libyan Sahara). Arid Zone Archaeology Monographs, 6, Edizioni all'Insegna del Giglio, Firenze.

Cremaschi, M., Zerboni, A., Spötl, C., Felletti, F., 2010. The calcareous tufa in the Tadrart Acacus Mt. (SW Fezzan, Libya). An early Holocene palaeoclimate archive in the Central Sahara. Palaeogeography, Palaeoclimatology, Palaeoecology 287, 81-94.

Cremaschi, M., Zerboni, A., Mercuri, A.M., Olmi, L., Biagetti, S., di Lernia, S., 2014. Takarkori rock shelter (SW Libya): an archive of Holocene climate and environmental changes in the central Sahara. Quaternary Science Reviews 101, 36-60. DOI: 10.1016/j.quascirev.2014.07.004.

de Benoist, J.-R., 1998. Le Mali. L'Harmattan, Paris.

Éguez, N., Biagetti, S., Zerboni, A., in press. Microstratigraphic analysis on a modern central Saharan pastoral campsite. Ovicaprine pellets and stabling floors as ethnographic and $\begin{array}{llll}\text { archaeological data. } & \text { Qferential }\end{array}$ doi.org/10.1016/j.quaint.2017.12.016

El-Ghali, K.M.A., 2005. Depositional environments and sequence stratigraphy of paralic glacial, paraglacial and postglacial Upper Ordovician siliciclastic deposits in the Murzuq Basin, SW Libya. Sedimentary Geology 177, 145-173.

Fiedermutz-Laun A., 2005. The House, the Hearth and the Granary - Symbols of Fertility among the West African Kasena. The Medieval History Journal 8, 247-265.

French, C.A.I., 1984. A sediments analysis of mud brick and natural features at El-Amarna. In: Kemp, B.J. (Ed.), Amarna Reports I. Occasional Papers 1. Egypt Exploration Society, London. Friesem, D., Boaretto, E., Eliyahu-Behar, A., Shahack-Gross, R., 2011. Degradation of mud brick houses in an arid environment: a geoarchaeological model. Journal of Archaeological Science $38,1135-1147$. 
Friesem, D., Wattez, J., Onfray, M., 2017. Earth construction materials. In: Nicosia, C., Stoops, G., (Eds.), Archaeological soil and sediments micromorphology. John Wiley and Sons Ltd, Hoboken, USA.

Gatto, M.C., 2010. The Garamantes of the Fazzan: Imported pottery and local productions. Bollettino di Archeologia on line Volume speciale A/A10/3, 30-38.

Gasse, F., 2000. Hydrological changes in the African tropics since the last glacial maximum. Quaternary Science Reviews 19, 189-211.

Gatto, M.C., Zerboni, A., 2015. Holocene supra-regional environmental changes as trigger for major socio-cultural processes in Northeastern Africa and the Sahara. African Archaeological Review 32, 301-333. DOI 10.1007/s10437-015-9191-x

Gé, T., Courty, M.-A., Matthews, W., Wattez, J., 1993. Sedimentary formation processes of occupation surfaces. In: Goldberg, P., Nash, D.T., Petraglia, M.D., (Eds.), Formation processes in archaeological context. Monographs in World Archaeology 17, Prehistory Press, Madison.

Goldberg, P., 1979. Geology of the Late Bronze Age mudbrick from Tel Lachish. Tel Aviv 6, 60-67. Goodman-Elgar, M., 2008. The devolution of mudbrick: ethnoarchaeology of abandoned earthen dwellings in the Bolivian Andes. Journal of Archaeological Science 35, 3057-3071.

Goren, Y., Goldberg, P., 1991. Petrographic thin-sections and the development of Neolithic plaster production in Northern Israel. Journal of Field Archaeology 18, 131-140.

Kemp, B., 2000. Soil (including mud-brick architecture). In: Nicholson, P.T., Shaw, I. (Eds.), Ancient Egyptian Materials and Technology. Cambridge University Press, Cambridge.

Klug, H.P., Alexander, E.L., 1974. X-Ray Diffraction Procedures: For Polycrystalline and Amorphous Materials. Wiley, New York.

Knight, J., Zerboni, A., 2018. Formation of desert pavements and the interpretation of lithic-strewn landscapes of the central Sahara. Journal of Arid Environments 153, 39-51. 
Kramer, R.S., Lobban Jr., R.A., Fluehr-Lobban, C., 2013. Historical dictionary of the Sudan. The Scarecrow Press, Plymouth, UK.

LaViolette, A., 1994. Masons of Mali: A Millennium of Design and Technology in Earthen Materials. In: Childs, S.T. (Ed.), Society, Culture, and Technology in Africa. MASCA Research Papers in Science and Archaeology, Philadelphia.

Liverani, M., 2004. Rediscovering the Garamantes: archaeology and history. Libyan Studies 35, 191-200.

Liverani, M., 2005. Aghram Nadharif. The Barkat Oasis. (Sha'abiya of Ghat, Libyan Sahara) in Garamantian Times. Arid Zone Archaeology Monographs, vol. 5, Edizioni All'Insegna del Giglio, Firenze.

Maas, P., Mommersteeg, G., 1992. Djenné: chef-d'oeuvre architectural. Institut Royal des Tropiques, Amsterdam.

MacDonald, K.C., 2011. A view from the south. Sub-Saharan evidence for contacts between North Africa, Mauritania and the Niger, 1000 BC-AD 700. In: Dowler, A., Galvin, E.R. (Eds.), Money, Trade and Trade Routes in Pre-Islamic North Africa. The British Museum Press, London.

Macphail, R.I., Goldberg, P., 2010. Archaeological materials. In: Stoops, G., Marcellino, V., Mees, F. (Eds.), Interpretation of micromorphological features of soil and regoliths. Elsevier, Amsterdam.

Matthews, W., Almond, M., Anderson, E., Wiles, J., Stokes, H., 2013. Biographies of architectural materials and buildings: integrating high-resolution micro-analysis and geochemistry. In: Hodder, I. (Ed.), Substantive technologies at Çatalhöyük: reports from the 2000-2008 seasons: Çatal Research Project vol. 9. British Institute at Ankara Monograph. Oxbow Books/British Institute of Archaeology at Ankara, Oxford. 
Mattingly, D.J., Daniels, C.M., Dore, J., Edwards, D., Hawthorne, J., (2003). The Archaeology of Fazzan. Volume 1, Synthesis. The Society for Libyan Studies/Department of Antiquities, London.

Mattingly, D.J., 2013. Survey and excavations at Old Jarma (ancient Garama) carried out by C.M. Daniels (1962-69) and the Fazzan Project (1997-2001). The Archaeology of Fazzan. Volume 4. The Society for Libyan Studies/Department of Antiquities, London.

Mattingly, D.J., Sterry, M., 2013. The first towns in the central Sahara. Antiquity 87, 503-518.

Mattone, R., 2003. La terra cruda, tra tradizione e innovazione. Costruire in Laterizio 92, 70-77.

McIntosh, R.J., 1974. Archaeology and mud wall decay in a West African village. World Archaeology 6, 154-171.

McIntosh, R.J., 1977. The Excavation of Mud Structures: An Experiment from West Africa. World Archaeology 9, 185-199.

Mercuri, A.M., Bosi, G., Buldrini, F., 2013. Seeds, fruits and charcoal from the Fewet compound. In: Mori, L. (Ed.), Life and Death of a Rural Village in Garamantian Times. Archaeological Investigations in the Fewet Oasis (Libyan Sahara), Arid Zone Archaeology Monographs, vol. 6. All'Insegna del Giglio, Firenze, pp. 177-190.

Miller Rosen, A., 1986. Cities of Clay: The Geoarchaeology of Tells. Prehistoric Archaeology and Ecology Series. The University of Chicago Press, Chicago.

Mori, L., 2013. Life and Death of a Rural Village in Garamantian Times. Archaeological Investigations in the Fewet Oasis (Libyan Sahara), Arid Zone Archaeology Monographs, vol. 6. All'Insegna del Giglio, Firenze.

Mori, L., Gatto, M.C., 2012. The Garamantes of the Fezzan and the Trans-Saharan trade in Roman times. In: Guedon, S. (ed.), Entre Afrique et_Egypte: relations et echanges entre les espaces au sud de la Mediterranee a l'epoque romaine. Actes du Colloque tenu a l'Universite de Limoges, 23-24 Septembre 2010. Ausonius, Paris. 
Murphy, C.P., 1986. Thin section preparation of soils and sediments. AB Academic Publishers, Berkhamsted.

Nicolini, I., Meucci, C., Pettiti, I., 2010. Characterization of Archaeological mud bricks from Sudan. Diagnostica per l'arte 3, [Online], Available at http://www.iacs.it/images/pdf/biblio/nicolini_meucci_pettiti.pdf (Accessed 22 May 2015).

Nicosia, C., Stoops, G., 2017. Archaeological soil and sediments micromorphology. John Wiley and Sons Ltd, Hoboken, USA.

Nodarou, E., Frederick, C., Hein, A., 2008. Another (mud)brick in the wall: scientific analysis of Bronze Age earthen construction materials from East Crete. Journal of Archaeological Science 35, 2997-3015.

Pecquet, L., 2004. The Mason and Banco, or Raw Material as a Power for Building a Lyela Home (Burkina Faso). Paideuma 50, 151-171.

Piniska, J., Hemdan, E.-M., 2008. Geomechanical study of building materials of the Hawara pyramid (Fayoum, Egypt). Geologija 50, 126-130.

Poch, R.M., Artieda, O., Herrero, J., Lebedeva-Verba, M., 2010. Gypsic features. In: Stoops, G., Marcellino, V., Mees, F., (Eds.), Interpretation of micromorphological features of soil and regoliths. Elsevier, Amsterdam.

Prussin, L., 1974. An Introduction to Indigenous African Architecture. Journal of the Society of Architectural Historians 33, 182-205.

Shahack-Gross, R., Marshall, F., Ryan, K., Weiner, S., 2004. Reconstruction of spatial organization in abandoned Maasai settlements: implications for site structure in the Pastoral Neolithic of East Africa. Journal of Archaeological Science 31, 1395-1411.

Shillito, L.-M., Matthews, W., 2013. Geoarchaeological investigations of midden-formation processes in the early to late Neolithic levels at Catalhoyuk, Turkey ca. 8550-8370 cal BP. Geoarchaeology 28, 25-49. 
Stevanovic M., 1997. The age of clay: the social dynamics of house destruction. Journal of Anthropological Archaeology 16, 334-395.

Stoops, G., 2003. Guidelines for analysis and description of soil and regolith thin sections. Soil Science Society of America, Madison.

Stoops, G., Marcellino, V., Mees, F., 2010. Interpretation of micromorphological features of soil and regoliths. Elsevier, Amsterdam.

Usai, D., Salvatori, S., 2002. The Is.I.A.O. el-Salha Archaeological Project. Sudan \& Nubia 6, 67-72.

Varanda, F., 2001. Project for the Restoration and Conservation of the city of Djenné. Technical Review Report, available at http://museologia.mestrados.ulusofona.pt/TxtFVaranda.pdf (Accessed 23 December 2017).

Walther, H., Lieth, H., 1960. Klimadiagramm. Weltatlas. G. Fisher, Jena.

Zerboni, A., 2011. Micromorphology reveals in situ Mesolithic living floors and archaeological features in multiphase sites in central Sudan. Geoarchaeology: an international journal 26, 365-391.

Zerboni, A., Bernasconi, A., Cremaschi, M., 2013. Micromorphological study of living floors and mud features from the excavation of Fewet. In: Mori, L. (Eds.), Life and death of a rural village in Garamantian Times. Archaeological investigations in the Fewet oasis (Libyan Sahara) (pp. 119-138). Arid Zone Archaeology Monographs, vol. 6. Edizioni all'Insegna del Giglio, Firenze.

Zerboni, A., Mori, L., Bosi, G., Buldrini, F., Bernasconi, A., Gatto, M.C., Mercuri, A.M., 2017. Domestic firing activities and fuel consumption in a Saharan oases: micromorphological and archaeobotanical evidence from Fewet (Central Sahara, SW Libya). Journal of Arid Environments 144, 123-138. http:// dx.doi.org/10.1016/j.jaridenv.2017.03.012.

Zerboni, A., Perego, A., Cremaschi, M., 2015. Geomorphological map of the Tadrart Acacus massif and the Erg Uan Kasa (Libyan Central Sahara). Journal of Maps 11, 772-787. DOI: 10.1080/17445647.2014.955891. 
Zerboni, A., Trombino, L., Cremaschi, M., 2011. Micromorphological approach to polycyclic pedogenesis on the Messak Settafet plateau (Central Sahara): Formative processes and palaeoenvironmental significance. Geomorphology 125, 319-335. 


\section{List of tables}

Tab. 1. Summary of field and micromorphological properties of each sample (classes of frequency: very few $<5 \%$, few 5-15\%; common $15-30 \%$; frequent $30-50 \%$; dominant $50-70 \%$; very dominant $>70 \%)$.

Tab. 2. Results of qualitative mineralogical phase analysis. Key for peaks intensity (e.g., relative abundance of mineral in each sample): ++++ dominant peaks; +++ peaks observed over the entire range; ++ the main peak well visible, but hard to distinguish the other peaks from the background, + the main peak can be just distinguished from the background.

\section{List of figures}

Fig. 1. (A) General view of North Africa illustrating the position of the study region and cited localities. (B) Landsat satellite imagery of the Fezzan (SW Libya, Central Sahara) indicating the position of the main Garamantian sites cited in the text. (C) Landsat satellite imagery of the southern Wadi Tanezzuft Valley illustrating the position of the modern villages of Fewet, Ghat, and Barkat; the location of the ancient citadel of Aghram Nadharif and the limits of the palaeo-oasis of Wadi Tanezzuft in Garamantian times (green shadow; modified after Cremaschi and Zerboni, 2013) are also indicated.

Fig. 2. (A) The oasis of Fewet from a Google Earth ${ }^{\mathrm{TM}}$ satellite imagery. The white star indicates the position of the compound, the black dot the outcrop of organic matter-rich swamp deposit; the white arrows are the outcrops of spring carbonates at the margin of the Tassili Massif. The position of the modern villages of Tan Afella and Tan Ataram is also reported, as long as the extension of the Garamantian necropolis (shadow). (B) A detail of the compound of Fewet in Google Earth ${ }^{\mathrm{TM}}$ satellite imagery.

Fig. 3. Plan of the excavation of the compound of Fewet, illustrating the location of each excavated room and the position of samples discussed in the paper. 
Fig. 4. (A) General view of the compound after excavation (the well is in the upper right corner) and $(\mathrm{B}, \mathrm{C})$ some details of the excavated rectangular rooms showing the earthen structures during the excavation. Note the stonewall supporting mud bricks all around the perimeter of the village.

Fig. 5. Photomicrographs of mud bricks from Fewet. (A) General view of the groundmass, note the large occurrence of sandy and silty-sized grains; the groundmass includes portions (on the right) largely impregnated by micrite (sample MB1, PPL); (B) portion of the slide of sample MB1 highly impregnated by calcium carbonate, which also displays sparitic recrystallization on voids (XPL); (C) elongate voids (indicated by the arrows) displaying a similar orientation that can be interpreted as pseudomorphic voids, which retain the shape of chaff eventually added as temper (sample MB2, XPL); (D) phosphate-rich nodules (indicated by the arrows) corresponding to a deformed and weathered coprolite englobed in the groundmass (sample MB2, PPL); (E) detail of (D) highlighting the occurrence of clusters of faecal spherulites (sample MB2, XPL); (F) faecal spherulites (sample MB2, XPL).

Fig. 6. Photomicrographs of calcium carbonate-rich features within the mud bricks from Fewet: (A, B) a large, rounded calcium carbonate pedorelict, possibly heated (sample MB3, XPL and PPL); (C) the arrow indicates a fragment of freshwater shell (sample MB2, XPL); (D) a fragment of freshwater algae (possibly genus Chara) in sample MB4 (PPL); (E) concentration of diatoms in a calcitic nodule (sample MB2, PPL); (F) a spicule of sponge (sample MB2, PPL).

Fig. 7. Photomicrographs of plasters from Fewet: (A) pseudomorphic voids (indicated by the arrows) that possibly retain the shape of chaff added as temper; the ends of moulded voids are angular and this may suggest that the chaff was pierced (sample PL2, XPL); (B) charcoal fragments (sample PL1, PPL); (C) cluster of lenticular gypsum crystals (sample PL3, XPL); (D) loose continuous infilling (indicated by the arrow) composed of lenticular and tabular gypsum crystals (sample PL3, XPL). 
Fig. 8. Photomicrographs of mortars from Fewet: (A) clay-rich groundmass (sample MT1, PPL); (B) micrite-rich groundmass, note the occurrence of palisade $\mathrm{CaCO}_{3}$ crystals along a planar void (sample MT1, XPL); (C) general view of the groundmass of sample MT2, note the preferential horizontal alignment of coarse grains due to compaction (PPL); (D) Fe-stained quartz grains (indicated by the arrows), note also the occurrence of few small gypsum crystals in the groundmass (sample MT1, XPL).

Fig. 9. Photomicrographs of modern example of mud bricks from Ghat and Mopti. (A) Massive structure of the mud brick from Ghat (PPL); (B) silt to sand quartz grains with interspersed few vegetal remains (indicated by the arrows) in the mud brick from Mopti (XPL); (C) fragments of clay coatings (indicated by the arrows) in the sample from Mopti (XPL).

Fig. 10. Photomicrographs of modern example of mud bricks from Sudan: (A) Fragments of decantation crusts in the groundmass of a mud brick from Al Khiday (PPL); (B) a few vegetal remains interspersed in the groundmass of a mud brick from Al Khiday (PPL); (C) mixture of a mud brick from Dangeil constituted by mineral grains and decantation crusts (PPL); (D) fissural microstructure of plaster from Al Khiday (PPL); (E) a detail of the plaster from $\mathrm{Al}$ Khiday showing a greater content of vegetal remains than in mud bricks (XPL); (F) a mud brick from Omdurman, extremely rich in vegetal remains and fragments of coprolites (PPL).

Fig. 11. X-ray powder diffraction pattern of analysed earthen features and marsh deposit close to Fewet in the $5-40^{\circ} 2 \theta$ range. Mineralogical phases label are: $Q$ for quartz, $C$ for calcite, $G$ for gypsum, A for anhydrite, $\mathrm{P}$ for plagioclase, $\mathrm{K}$ for $\mathrm{K}$-feldspar, $\mathrm{Ka}$ for kaolinite, and $\mathrm{M}$ for mica.

Fig. 12. Pictures illustrating the building of the modern perimeter wall encircling the compound of Fewet (year 2004): (A) preparation of shallow foundation around the compound (on the right); (B) positioning of a single row of sandstone slabs and blocks; (C) area designated to the preparation of mud bricks with local resources with piles of sun-baked bricks. 
Fig. 13. (A) A collapsed mud bricks wall found during the excavation of the compound of Fewet and (B) a modern analogue in the village of Tan Ataram (picture taken in year 2003).

Fig. 14. An old wall in Fewet (Tan Afella) that suffered strong weathering (year 2004). Note the flanking of plaster at the basis of the wall (indicated by the arrows), which possibly is the result of the process described by McIntosh (1974) and identified at ancient Fewet.

Fig. 15. Modern earthen architectures in the Libyan Fezzan: (A) abandoned building in Fewet (year 2004); (B) panoramic view of the old city of Ghat (year 2003); (C) fresh plaster covering the walls of Tunin (Ghat) in 2004; (D) old house in Barkat (year 2009); (E) perimetral wall of an earthen house under construction at Jerma (notice on the left the occurrence of locally produced mud bricks backing in the sun (year 2010); (F) a detail of the mud bricks wall in Jerma, illustrating the texture of modern mud bricks and mortar (year 2010). 


\section{Highlights}

- We investigated earthen architectural structures at ancient Fewet (Libya)

- XRD and thin section micromorphology reveal the composition of earthen features

- In the 2000 years old Fewet mud brick were prepared without adding vegetal

- The same mixture for earthen features have been observed today in the Sahara and Sahel

- We propose the possibility of a technological continuity from the late Antiquity up to today 

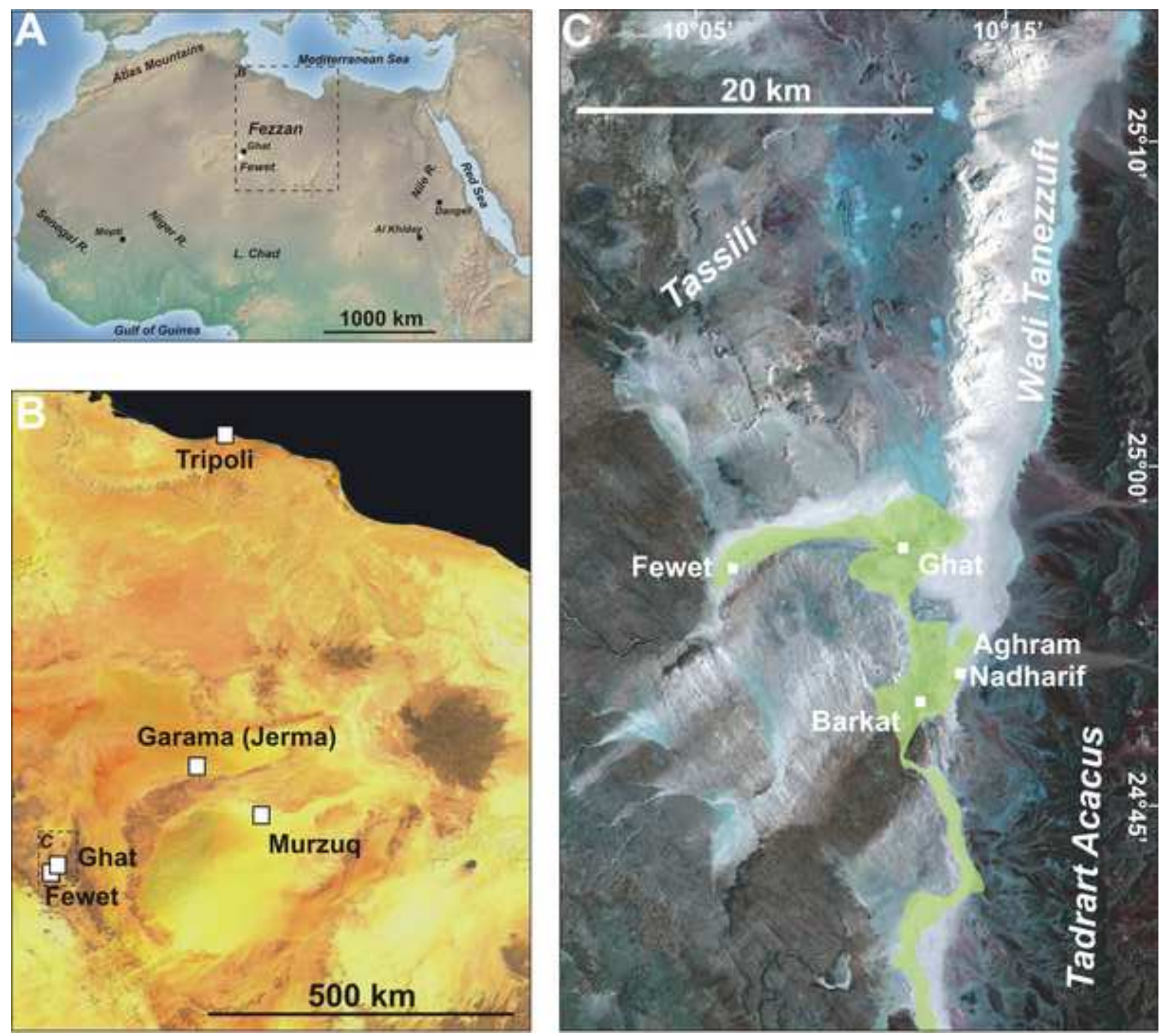
Click here to download high resolution image

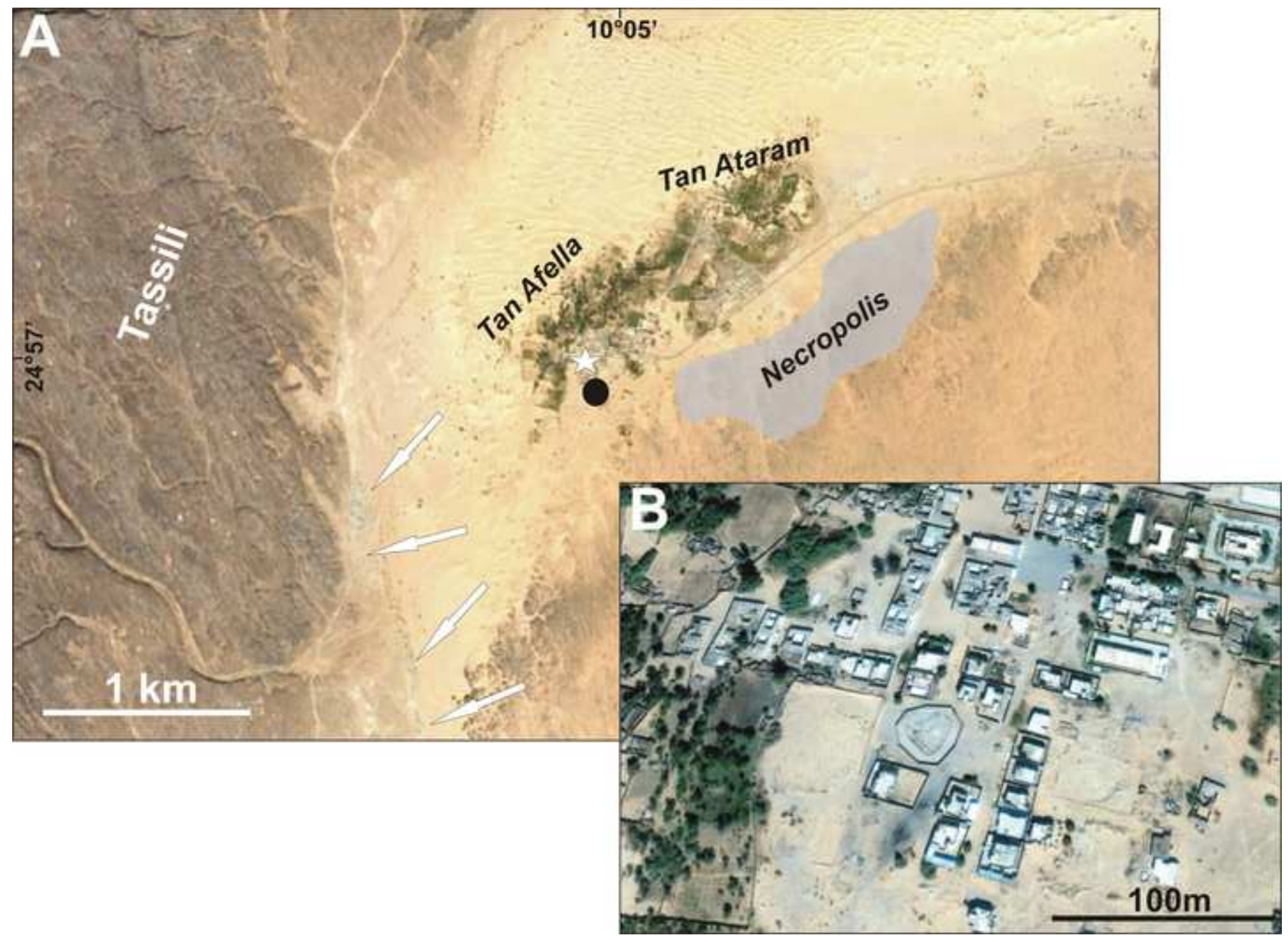







Click here to download high resolution image


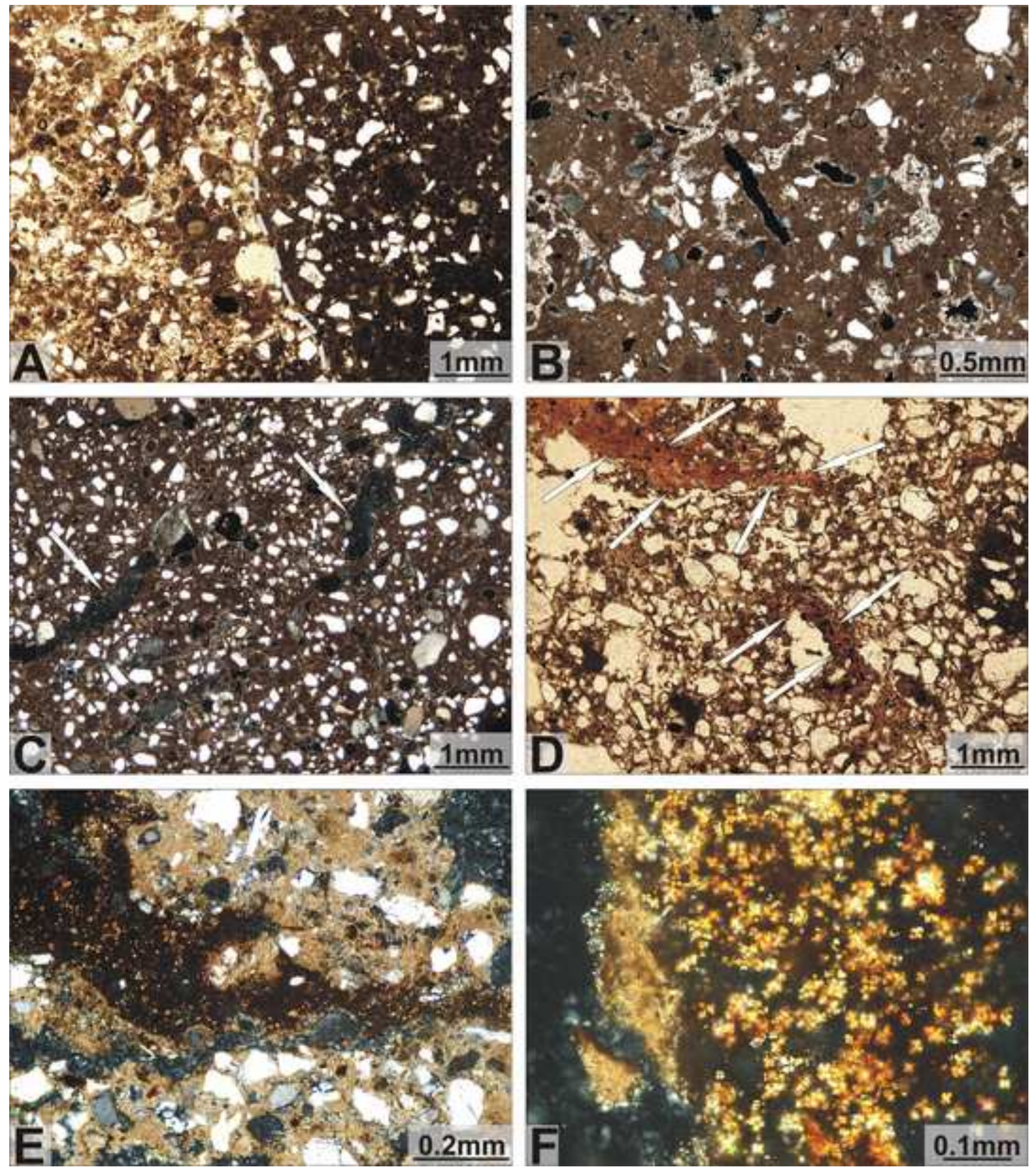

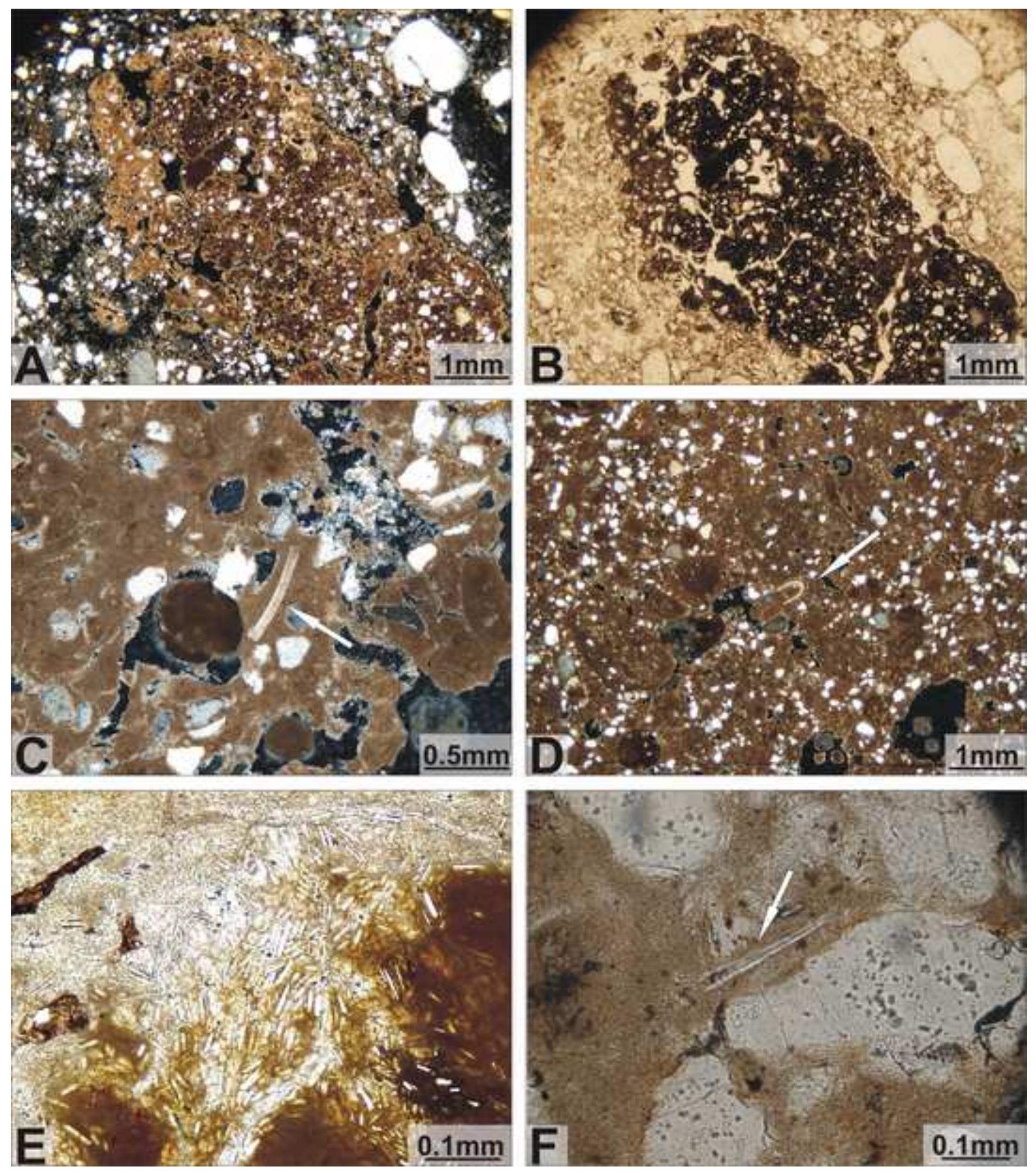
Figure 7

Click here to download high resolution image
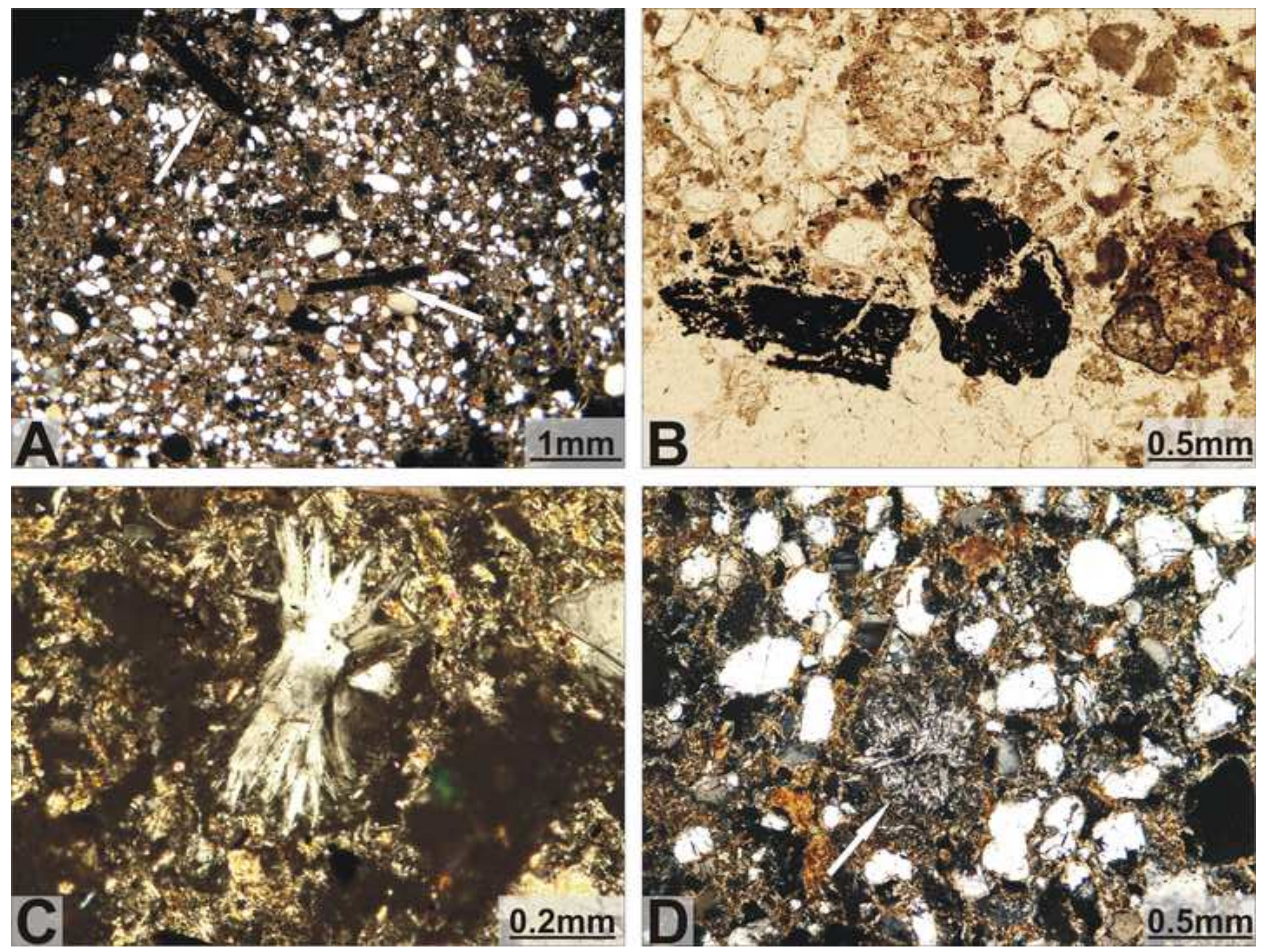
Click here to download high resolution image

Click here to download high resolution image


whe

A 0 (x) $0.5 \mathrm{~mm}$ 

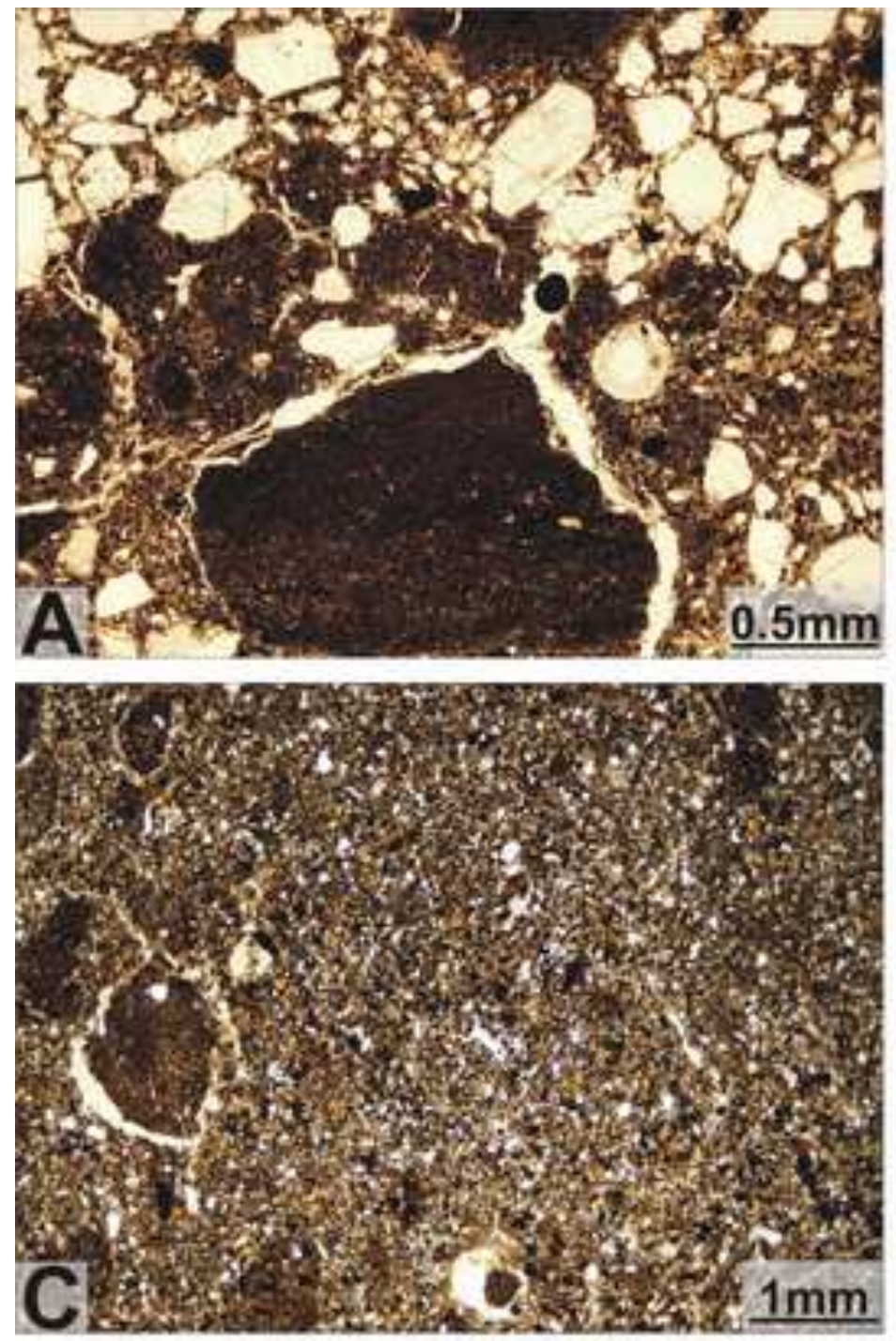





Click here to download high resolution image
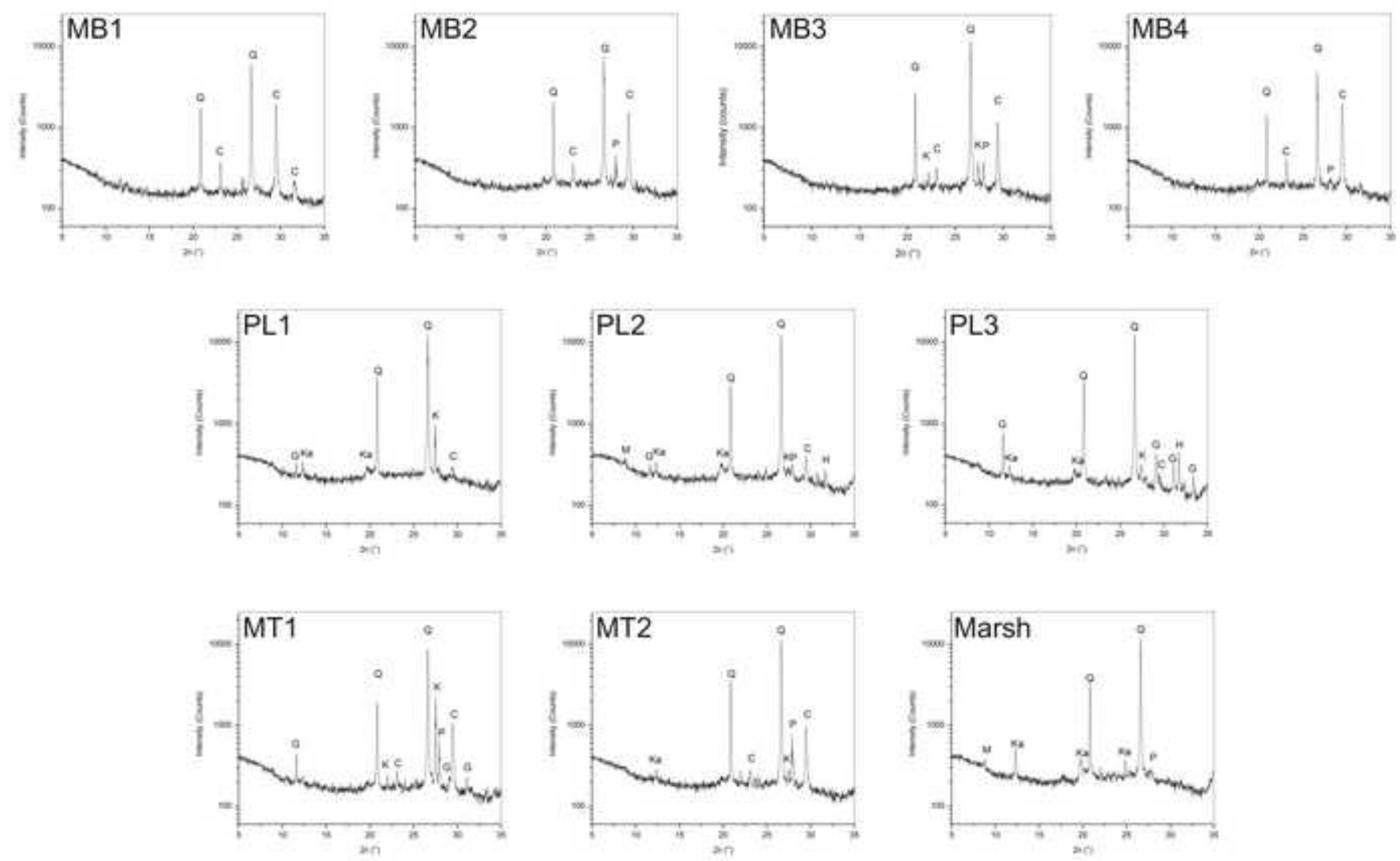
Click here to download high resolution image

Click here to download high resolution image
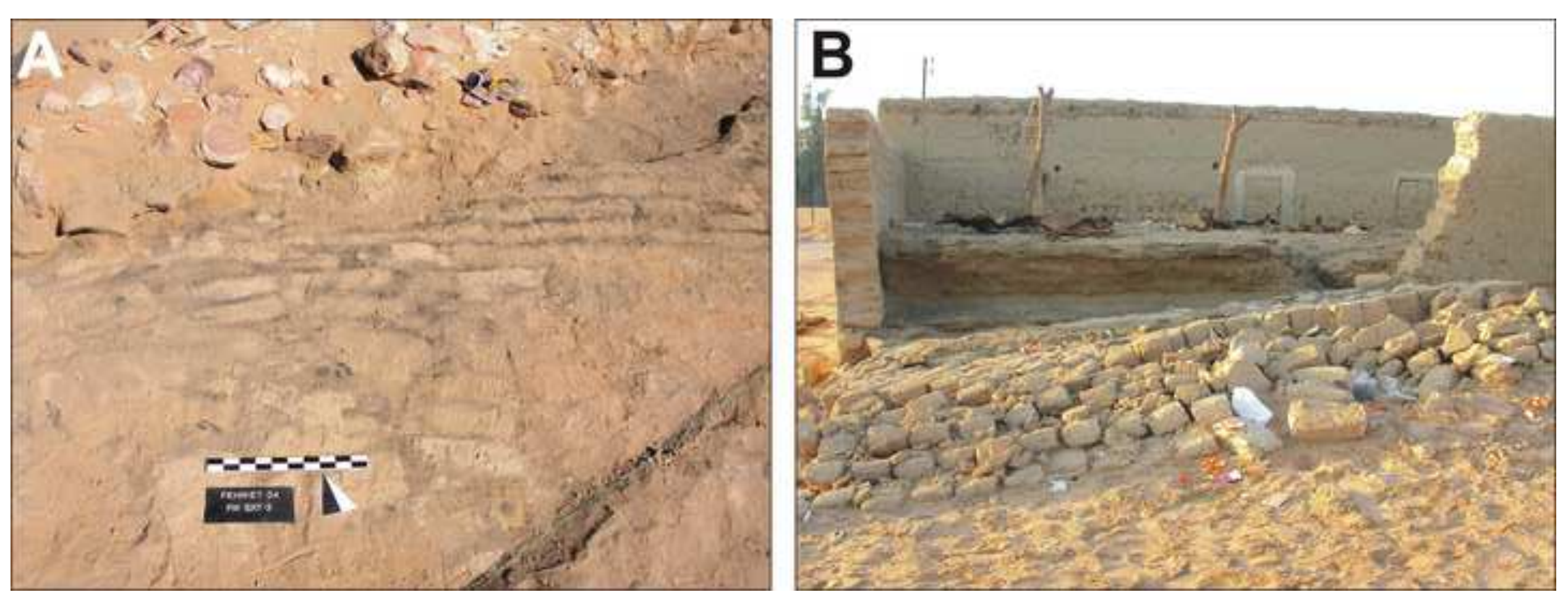
Click here to download high resolution image

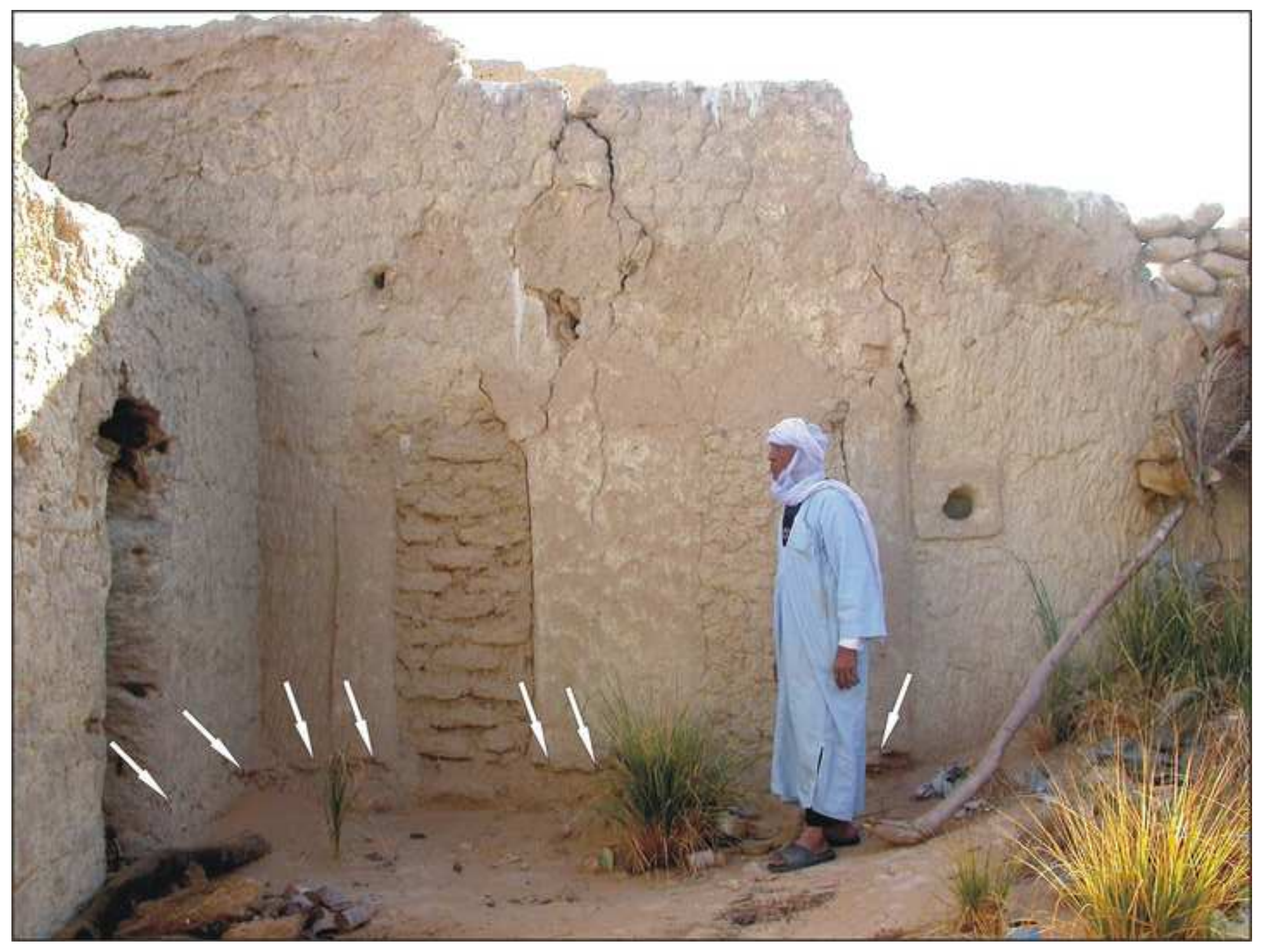

Figure 14 
Click here to download high resolution image
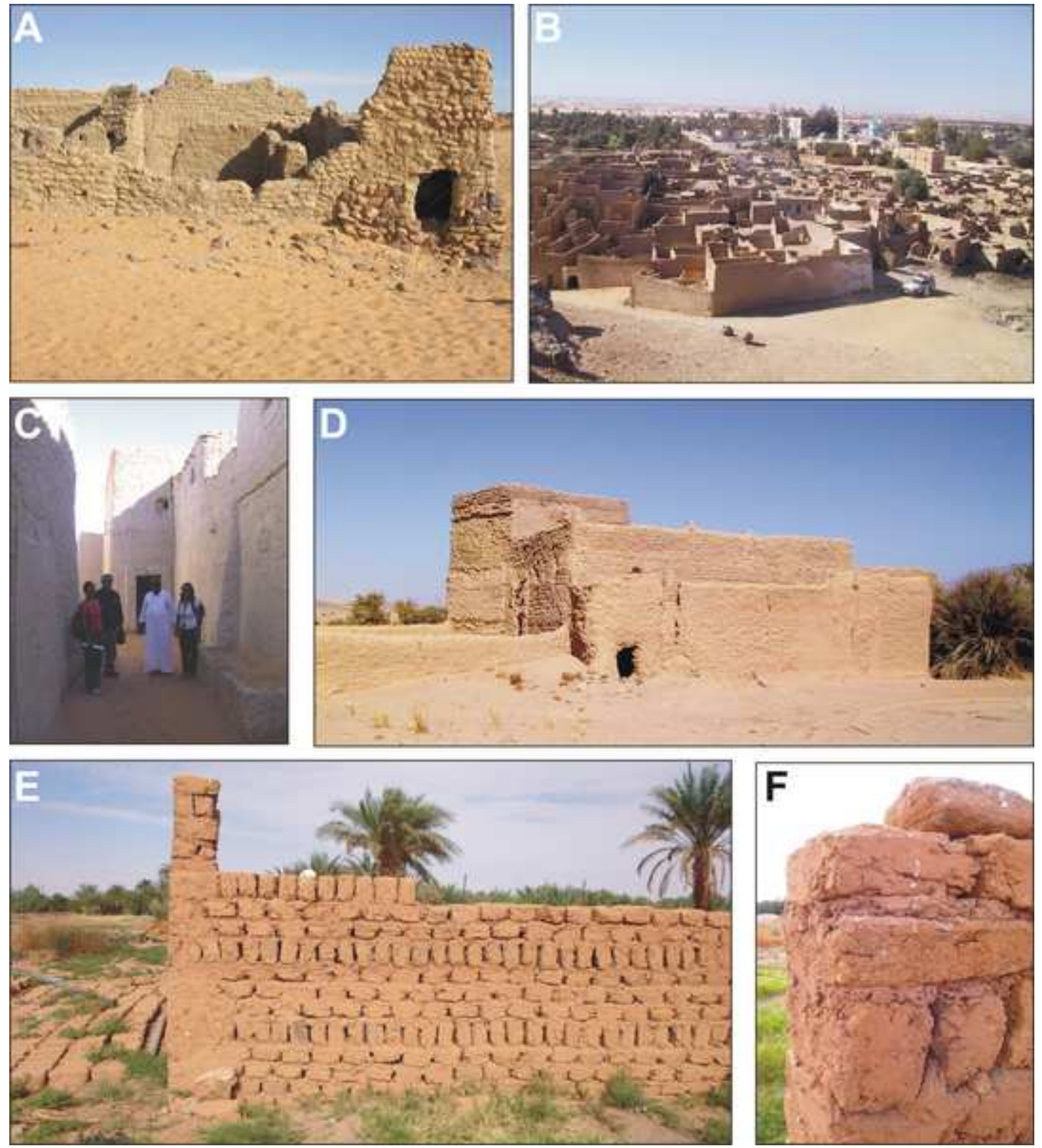


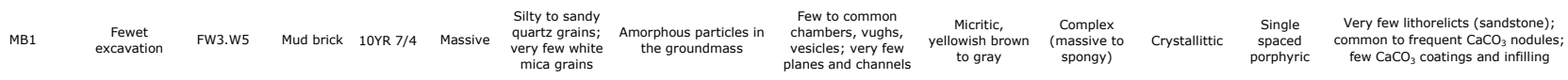

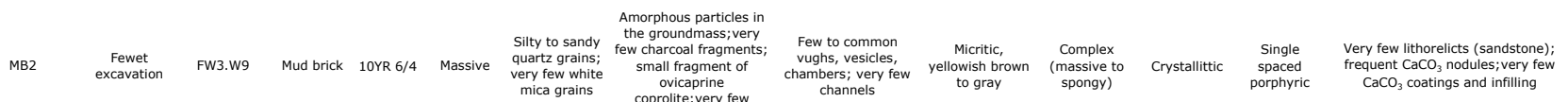



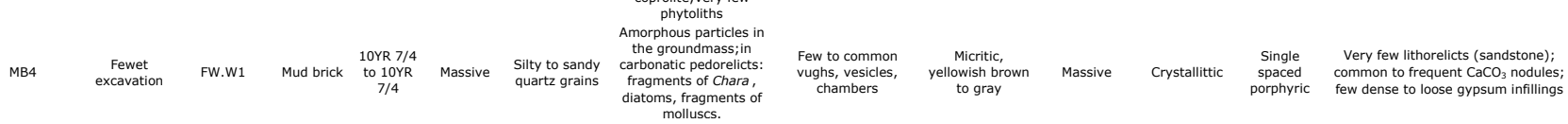



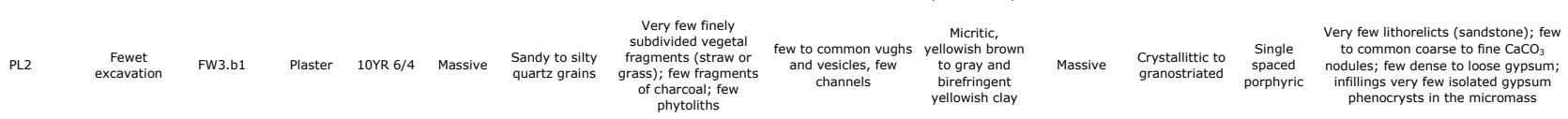



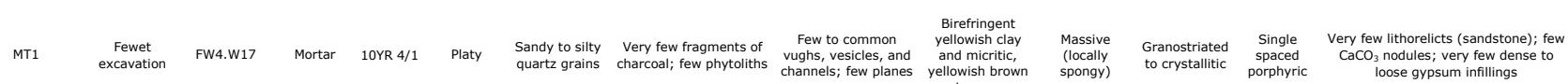

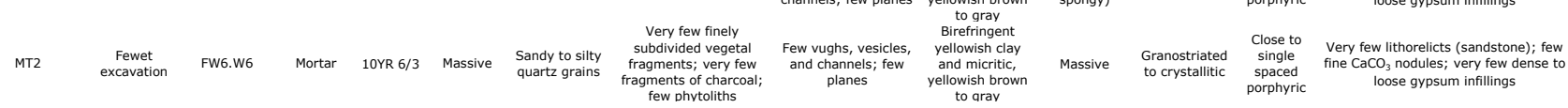



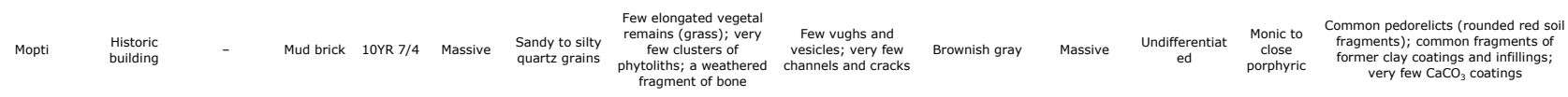

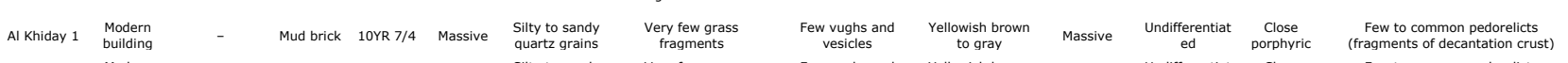

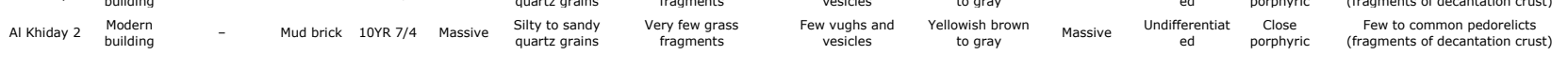

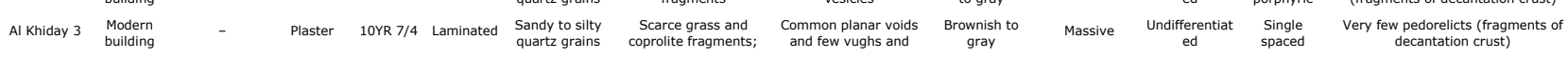

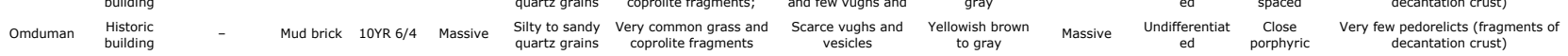

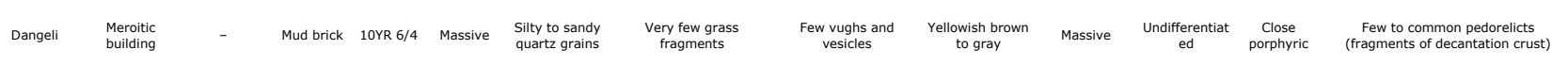


Table 2. Results of qualitative mineralogical phase analysis. Key for peaks intensity (e.g., relative abundance of mineral in each sample): ++++ dominant peaks; +++ peaks observed over the entire range; ++ the main peak well visible, but hard to distinguish the other peaks from the background, + the main peak can be just distinguished from the background.

\begin{tabular}{|c|c|c|c|c|c|c|c|c|}
\hline Sample & Quartz & Calcite & K-feld & Plagioclase & Gypsum & Kaolinite & Halite & Mica \\
\hline MB1 & ++++ & +++ & - & - & - & - & - & - \\
\hline MB2 & ++++ & +++ & - & ++ & - & - & - & - \\
\hline MB3 & ++++ & +++ & ++ & ++ & - & - & - & - \\
\hline MB4 & ++++ & +++ & - & + & - & - & - & - \\
\hline PL1 & ++++ & + & +++ & - & + & + & - & - \\
\hline PL2 & ++++ & ++ & - & + & + & ++ & + & + \\
\hline PL3 & ++++ & ++ & + & - & ++ & + & + & - \\
\hline MT1 & ++++ & +++ & +++ & ++ & ++ & - & - & - \\
\hline MT2 & ++++ & +++ & + & ++ & - & + & - & - \\
\hline Marsh & +++ & +++ & - & + & ++++ & +++ & ++ & + \\
\hline
\end{tabular}

